\title{
LIFE AFTER BILSKI ${ }^{\dagger}$
}

\section{Mark A. Lemley, ${ }^{*}$ Michael Risch, ${ }^{* *}$ Ted Sichelman*** \& R. Polk Wagner****}

In Bilski v. Kappos, the Supreme Court declined calls to categorically exclude business methods-or any technology - from the patent law. It also rejected as the sole test of subject matter eligibility the Federal Circuit's deeply-flawed machine-or-transformation test, under which no process is patentable unless it is tied to a particular machine or transforms an article to another state or thing. Subsequent developments threaten to undo that holding, however. Relying on the Court's description of the Federal Circuit test as a "useful and important clue," the U.S. Patent and Trademark Office, patent litigants, and district courts have all continued to rely on the machine-or-transformation test in the wake of Bilski: no longer as the sole rule, but as a presumptive starting point that threatens to effectively become mandatory. In this Article, we suggest a new way to understand the exclusion of abstract ideas from patentable subject matter. No class of invention is inherently too abstract for patenting. Rather, the rule against patenting abstract ideas is an effort to prevent inventors from claiming their ideas too broadly. By requiring that patent claims be limited to a specific set of practical applications of an idea, the abstract ideas doctrine both makes the scope of the resulting patent clearer and leaves room for subsequent inventors to improve upon-and patent new applications of -the same basic principle. Recasting the abstract ideas doctrine as an overclaiming test eliminates the constraints of the artificial machine-or-transformation test, as well as the pointless effort to fit inventions into permissible or impermissible categories. It also helps understand some otherwise-inexplicable distinctions in the case law. Testing for overclaiming allows courts to focus on what really matters: whether the scope of the patentee's claims are commensurate with the invention's practical, real-world contribution. This inquiry, we suggest, is the touchstone of the abstract ideas analysis, and the way out of the post-Bilski confusion.

$\dagger$ (C) 2011 The authors and the Trustees of Leland Stanford Jr. University.

* William H. Neukom Professor, Stanford Law School; Partner, Durie Tangri LLP.

** Associate Professor, Villanova University School of Law.

*** Assistant Professor, University of San Diego School of Law.

**** Professor of Law, University of Pennsylvania Law School.

Thanks to Rose Hagan and the participants at the Stanford Law Review symposium on Bilski for comments on a previous draft, and to Dustin Bednarz for research assistance. 
INTRODUCTION.

I. ThE RETURN OF MACHINE-OR-TRANSFORMATION.......................................1317

A. The History of Patenting Software ......................................................1317

B. The Persistence of the Machine-or-Transformation Test..........................1319

C. The Perils of the Machine-or-Transformation Test...................................1322

II. The Theory OF SubJEct MAtTER Restrictions............................................1325

A. Prior Subject Matter Theories .................................................................1326

B. Abstract Ideas as Scope Limitation .......................................................1328

C. Distinguishing the Scope Limitations in $\S 101$ and $\S 112$......................1329

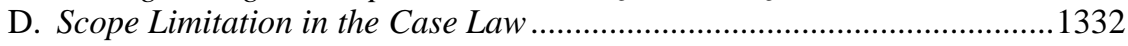

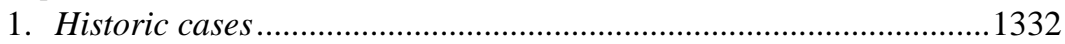

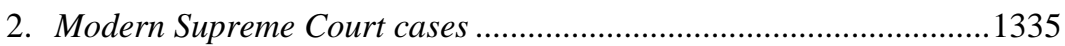

III. A PROPER APPROACH TO IDENTIFYING CLAIMS THAT IMPERMISSIBLY

COVER ABSTRACT IDEAS......................................................................1337

A. The Failure of the Machine-or-Transformation Test .............................1338

B. Identifying Abstract Ideas .................................................................1339

C. Overclaiming and the Decision Process ...................................................1341

D. Applying the Scope-Based Patentable Subject Matter Analysis ................1342

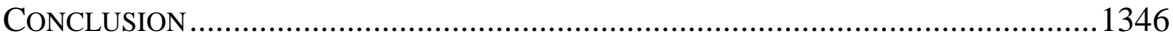

\section{INTRODUCTION}

In Bilski v. Kappos, the Supreme Court rejected calls to categorically exclude business methods - or any technology — from the scope of patent law. ${ }^{1}$ It also rejected as the sole test of subject matter eligibility the Federal Circuit's deeply-flawed machine-or-transformation test, under which no process, and perhaps no invention of any type, is patentable unless it is tied to a particular machine or transforms an article to another state or thing. ${ }^{2}$ Nonetheless, the Court held that the machine-or-transformation test still "is a useful and important clue, an investigative tool, for determining whether some claimed inventions" are patentable subject matter. ${ }^{3}$ The result was a (narrow) victory for inventors, as well as for context-specific standards over formal rules.

Subsequent developments threaten to undo that win, however. Relying on the Court's "useful and important clue" language, the U.S. Patent and Trademark Office (PTO), patent litigants, and district courts have all continued to rely on the machine-or-transformation test in the wake of Bilski: no longer as the sole rule, but as a presumptive starting point that threatens to become effectively mandatory. Put simply, the problem is that no one understands what makes an idea "abstract,"4 and hence ineligible for patent protection, so decisionmakers fall back on the one test that has been articulated.

1. 130 S. Ct. 3218 (2010).

2. See In re Bilski, 545 F.3d 943, 954 (Fed. Cir. 2008) (en banc).

3. $130 \mathrm{~S}$. Ct. at 3227.

4. See Interim Guidance for Determining Subject Matter Eligibility for Process Claims in View of Bilski v. Kappos, 75 Fed. Reg. 43,922 (July 27, 2010) (providing an ex- 
In this Article, we suggest a new way to understand the exclusion of abstract ideas from patentable subject matter. No class of invention is inherently too abstract for patenting. Rather, the rule against patenting abstract ideas is best understood as an effort to prevent inventors from claiming their ideas too broadly. By requiring that patent claims be limited to a specific set of practical applications of an idea, the abstract ideas doctrine both makes the scope of the resulting patent clearer and leaves room for subsequent inventors to improve upon - and patent new applications of - the same basic principle.

Understanding the abstract ideas doctrine as an overclaiming test eliminates the constraints of the artificial machine-or-transformation rule, as well as the pointless effort to fit inventions into permissible and impermissible categories. It also helps understand some otherwise-inexplicable distinctions in the case law. A focus on overclaiming allows courts to focus on what really matters: whether the scope of the patentee's claims is commensurate with the invention's practical, real-world contribution, rather than asserting coverage over general ideas unmoored to a specific application. This inquiry, we suggest, is the touchstone of the abstract ideas analysis, and the way out of the post-Bilski confusion.

In Part I, we discuss the rise, fall, and apparent rebirth of the Federal Circuit's machine-or-transformation test, and explain why it is so problematic. In Part II, we offer a new way of thinking about abstract ideas, one focused on the scope of the patentee's claims rather than the category of the invention. In Part III, we apply our test to a variety of current cases and problems.

\section{THE RETURN OF MACHINE-OR-TRANSFORMATION}

\section{A. The History of Patenting Software}

The patentability of software and business methods has a long and tortured history. Put extremely briefly: The Supreme Court in the 1970s struggled with mathematical algorithm and software patents, first refusing to patent a mathematical algorithm, ${ }^{5}$ but later holding that a process could be patented even though its novel elements included software so long as that software was tied to a particular machine. ${ }^{6}$ After these cases, the Supreme Court got out of the business of patentable subject matter for nearly thirty years. ${ }^{7}$

planation of considerations to use in determining subject matter eligibility of method claims in view of the abstract idea exception).

5. See Parker v. Flook, 437 U.S. 584, 594-95 (1978); Gottschalk v. Benson, 409 U.S. 63, 65, 71-72 (1972).

6. See Diamond v. Diehr, 450 U.S. 175, 187, 191-93 (1981) ("On the other hand, when a claim containing a mathematical formula implements or applies that formula in a structure or process which, when considered as a whole, is performing a function which the patent laws were designed to protect (e.g., transforming or reducing an article to a different state or thing), then the claim satisfies the requirements of $\S 101 \ldots$. [W] do not view res- 
Through the 1980s and 1990s, courts gradually eroded the requirement that a software invention be tied to a particular machine. ${ }^{8}$ Finally, in 1998, in State Street, the Federal Circuit eliminated any such requirement, holding that both software alone and business methods were patentable regardless of the form in which they were implemented, if the invention produced a "useful, concrete, and tangible result," even one expressed in numbers. ${ }^{9}$

For a decade after 1998, patentable subject matter was effectively a dead letter. That changed dramatically in 2008 when the Federal Circuit decided In re Bilski en banc. The case involved a patent application on a method of hedging risk in the sale of commodities. The patent application also included dependent claims that limit the method to use in the energy industry and one dependent claim that offers a formula for calculating risk-adjusted prices. The FederFederal Circuit ruled, eleven to one, that Bilski's claimed method of hedging financial risk was unpatentable. ${ }^{10}$

The Federal Circuit crafted what has come to be known as the machine-ortransformation test: “A claimed process is . . p patent-eligible under $\S 101$ if: (1) it is tied to a particular machine or apparatus, or (2) it transforms a particular article into a different state or thing."11

Moreover, even if a process meets this test, it is unpatentable if the machine or transformation is merely incidental extra-solution activity. ${ }^{12}$ And an invention that preempts all use of a law of nature or algorithm, even in a particular field of use, is not patentable even if it would otherwise survive the test. Purporting to derive this test from Supreme Court precedent, the Federal Circuit displaced all prior tests for patentable subject matter, including State Street's "useful, concrete, and tangible result" analysis. ${ }^{13}$

The Supreme Court granted certiorari and affirmed that Bilski's invention was unpatentable as an abstract idea. ${ }^{14}$ However, the Court rejected the machine-or-transformation analysis as the exclusive test of patentability, ${ }^{15}$ though

pondents' claims as an attempt to patent a mathematical formula, but rather to be drawn to an industrial process for the molding of rubber products ....”).

7. The one exception-J.E.M. Ag Supply, Inc. v. Pioneer Hi-Bred Int'l, Inc., 534 U.S. 124 (2001) — involved the interaction of the patent statute with other specialized statutes protecting plants.

8. For a discussion of this history, see Julie E. Cohen \& Mark A. Lemley, Patent Scope and Innovation in the Software Industry, 89 CALIF. L. REV. 1 (2001).

9. State St. Bank \& Trust Co. v. Signature Fin. Grp., 149 F.3d 1368, 1373 (Fed. Cir. 1998) (internal quotation marks omitted).

10. In re Bilski, 545 F.3d 943 (Fed. Cir. 2008) (en banc). While there were three dissents, only Judge Pauline Newman would have found the claims to be patentable subject matter.

11. Id. at 954 .

12. See id. at 957.

13. Id. at 959-61.

14. See Bilski v. Kappos, 130 S. Ct. 3218, 3229-30 (2010).

15. See id. at 3227. 
all the Justices thought that the test was an "important clue" to patentability. ${ }^{16}$ Alas, the Court's majority did not provide additional guidance on why Bilski's invention was unpatentable. ${ }^{17}$

\section{B. The Persistence of the Machine-or-Transformation Test}

Patent owners narrowly dodged a bullet in Bilski. No one except perhaps Bilski himself thought that he would get a patent. ${ }^{18}$ However, four Justices would have held business methods unpatentable altogether, ${ }^{19}$ and in the course of doing so would have substantially limited patentable subject matter. Thus, the fact that Justice Kennedy's opinion for the Court rejected strict application of the machine-or-transformation test and left open the prospect of patenting software and business methods led early commentators to declare it a victory for patent owners in those industries. ${ }^{20}$

In fact, the PTO and the few district courts to have decided cases since Bilski have continued to apply the machine-or-transformation test. For example, in Ultramercial, $L L C$ v. Hulu, $L L C$, the claims related to the process of displaying copyrighted media in exchange for watching certain advertising. ${ }^{21}$ The district court held that "even though the machine or transformation is no longer the litmus test for patentability, the Court will use it here as a key indicator of patentability."22

The PTO Board of Patent Appeals and Interferences (BPAI) has similarly focused on the machine-or-transformation test in analyzing post-Bilski claims. ${ }^{23}$ In Ex parte Tse-Huong Choo, the BPAI rejected a claim that it found "can exist solely in software and data structures."24 More importantly, the

16. Id. at 3227; id. at 3235 (Stevens, J., concurring in the judgment); id. at 3258 (Breyer, J., concurring in the judgment).

17. See, e.g., Kristen Osenga, Waiting for Bilski: A Patent Story 5 (July 12, 2010) (unpublished manuscript), available at http://papers.ssrn.com/sol3/papers.cfm?abstract_id $=1650061$ ("In the end, [Bilski] tells Bar and Academy nothing more than has already been said. The men remain in the same fog of confusion.”).

18. In fact, the Bilski patent had a co-inventor, Rand Warsaw. See Bilski, 130 S. Ct. at 3218. However, for simplicity, we assume in the text that Bilski was the sole inventor.

19. See id. at 3249 (Stevens, J., concurring in the judgment). Indeed, many believe that the concurrence was originally to be the majority opinion.

20. See, e.g., Peter S. Menell, Forty Years of Wondering in the Wilderness and No Closer to the Promised Land: Bilski's Superficial Textualism and the Missed Opportunity to Return Patent Law to Its Technology Mooring, 63 STAN. L. REV. 1289 (2011).

21. See No. CV 09-06918 RGK (PLAx), 2010 WL 3360098, at *1 (C.D. Cal. Aug. 13, 2010).

22. $I d$. at $* 3$.

23. For a full discussion of all board opinions since Bilski, see Dave Healey, BPAI: Tough on Software Claims Post-Bilski, РАT. МATH (Dec. 7, 2010), http://patentmath.com/ bpai-tough-on-software-claims-post-bilski.

24. No. 2009-006352, 2010 WL 2985362, at *2 (B.P.A.I. July 28, 2010). 
Board looked at a Beauregard claim ${ }^{25}$ and found that "merely reciting data or instructions on a stored computer readable medium does not make a claim statutory [subject matter] under $\S 101$. Similarly, merely placing instructions or code on a computer readable medium does not render claim 24 statutory.,26 Thus, the Board concluded that Bilski bars not just process but also article-ofmanufacture claims to software standing alone. ${ }^{27}$

The Board has been equally strict in applying the transformation step of the machine-or-transformation test to software. In Ex parte Heuer, the Board rejected a claim to a method for decoding a binary representation of a document. $^{28}$ The BPAI found that the claims failed both prongs of the machine-ortransformation test. It specifically looked at an "XML-based document," "a simplified schema," "a schema," "correction code," and "at least one decoder" and found that nothing in the specification indicating that they "must be hardware" and that there was therefore no machine. ${ }^{29}$ On the transformation side, the BPAI found that " $[\mathrm{t}] \mathrm{he}$ fact that Appellants' XML-based document is decoded using the claimed 'namespace' or the claimed 'simplified schema' fails to qualify as a transformation of an article of manufacture consistent with the second prong of the 'machine-or-transformation' test." ${ }^{30}$ The latter ruling seems to be more restrictive than the Federal Circuit decision in In re Bilski, since it doesn't permit transformation of anything other than an article of manufacture, while the Federal Circuit had appeared willing in Bilski to allow some transformations of data to meet the machine-or-transformation test. ${ }^{31}$

The PTO issued guidance in interpreting Bilski in July 2010, identifying various factors that could affect patentable subject matter eligibility; all of

25. Beauregard claims are directed to software stored on a medium such as a CDROM claimed as an article of manufacture. See In re Beauregard, 53 F.3d 1583, 1584 (Fed. Cir. 1995).

26. Tse-Huong Choo, 2010 WL 2985362, at *5 (citations omitted); accord Ex parte Kelkar, No. 2009-004635, 2010 WL 3768175 (B.P.A.I. Sept. 24, 2010).

27. See also Ex parte Christian, No. 2009-006589, 2010 WL 3389297, at *2 (B.P.A.I. Aug. 23, 2010) ("A claim that recites no more than software, logic, or a data structure (i.e. an abstraction) does not fall within any statutory category. . . . 'Abstract software code is an idea without physical embodiment.'” (citation omitted) (quoting Microsoft Corp. v. AT\&T Corp., 550 U.S. 437, 449 (2007))); Ex parte Ramanujam, No. 2009-002483, 2010 WL 3214559 , at *4 (B.P.A.I. Aug. 12, 2010) (finding that claims "are therefore directed to software per se, which falls outside the scope of patentable subject matter”); Ex parte Caccavale, No. 2009-006026, 2010 WL 2901727, at *5 (B.P.A.I. July 23, 2010) (“Claim 8 simply fails to recite that the computations are performed by the 'distributed processing units' or any other machine in claim 8.”). Contra Ex parte Russo, No. 2009-001876, 2010 WL 3441058 (B.P.A.I. Aug. 30, 2010) (holding a system claim directed to data structures unpatentable, but a Beauregard claim to the same data structures patentable).

28. No. 2009-004590, 2010 WL 3072973 (B.P.A.I. Aug. 4, 2010); accord Ex parte Venkata, No. 2009-007302 (B.P.A.I. Oct. 5, 2010); Ex parte MacKenzie, No. 2009-007332 (B.P.A.I. Oct. 4, 2010).

29. Heuer, 2010 WL 3072973 , at *8.

30. Id.

31. See In re Bilski, 545 F.3d 943, 961-63 (Fed. Cir. 2008) (en banc). 
those factors relate generally to the machine-or-transformation test or are implementations of it. ${ }^{32}$ We have heard reports that patent examiners are more lenient than the Board generally has been, allowing claims to general-purpose computers programmed with software and rejecting only pure software claims. ${ }^{33}$ But by the nature of the appellate process, it is the Board decisions that are likely to shape the law in future cases.

In December 2010, the Federal Circuit decided Research Corp. Technologies v. Microsoft Corp., holding that software method claims directed to a process of "halftoning" printed images were not unpatentable abstract ideas because the invention "presents functional and palpable applications in the field of computer technology." 34 The opinion noted that other (unasserted) claims in the patent required the use of specific machines, demanded evidence that the claim be "manifestly abstract" before holding it invalid, and went so far as to suggest that "inventions with specific applications or improvements to technologies in the marketplace are not likely to be so abstract” as to fail § $101 .^{35}$ The court did not apply the machine-or-transformation test, and indeed suggested (wrongly) that the Supreme Court had rejected that test as nonstatutory. ${ }^{36}$ The court suggested that $\S 112$ may better serve the goal of limiting overbroad claim language. ${ }^{37}$

Research Corp. is an encouraging sign that the machine-or-transformation test may not dominate the post-Bilski landscape. Indeed, it might suggest a return to the State Street form of analysis. But some caution is warranted. The case was written by Judge Rader, and joined by Judge Newman, the two judges who dissented from the machine-or-transformation test in In re Bilski. It contains some specious reasoning that is hard to square with prior court precedent, such as its conclusion that structural limitations in dependent claims render patentable different, independent claims that lack those limitations. ${ }^{38}$ And it does

32. See Interim Guidance for Determining Subject-Matter Eligibility for Process Claims in View of Bilski v. Kappos, 75 Fed. Reg. 43,922 (July 27, 2010).

33. One Board opinion supports this more lenient approach. See Ex parte Ulf, No. 2009-008071, 2010 WL 3611779, at *8 (B.P.A.I. Sept. 7, 2010) (“Dependent claim 4 explicitly recites 'an inquiry, made on an opportunity reservation computer database.' In particular, since a computer is required to query a computer database, we find evidence that the method steps of dependent claim 4 are implemented on a 'machine.' Therefore, claim 4 is tied to a 'machine' consistent with the bounds of the machine-or-transformation test."). But see Ex parte Aklilu, No. 2009-007075, 2010 WL 4315178, at *4 (B.P.A.I. Oct. 29, 2010) ("[M]ere use of a generic machine or a general purpose computer to perform the steps of an otherwise unpatentable algorithm is not sufficient to meet the requirements for $\S 101$ statutory subject matter.”).

34. 627 F.3d 859, 868 (Fed. Cir. 2010).

35. Id. at 869 .

36. See id. at 868 .

37. See id. at 869.

38. See id. ("The fact that some claims in the '310 and '228 patents require a 'high contrast film,' 'a film printer,' 'a memory,' and 'printer and display devices' also confirm [sic] this court's holding that the invention is not abstract.”). 
not offer a detailed test of its own, instead simply holding that the claims at issue are not abstract (albeit with some discussion). Given that the Federal Circuit created the machine-or-transformation test, it seems quite possible that the majority of the court will incline to the views of the BPAI and the district courts that the machine-or-transformation test continues to govern in most instances, distinguishing Research Corp. on its facts.

Indeed, some reason to think that likely came just over a week later, in Prometheus Laboratories, Inc. v. Mayo Collaborative Services. ${ }^{39}$ The court there reaffirmed the patentability of a method for optimizing drug dosages during therapy. But in doing so, the Federal Circuit held that the Supreme Court "did not disavow the machine-or-transformation test" and had instead indicated "that " $\mathrm{t}$ ]ransformation and reduction of an article to a different state or thing is the clue to the patentability of a process claim that does not include particular machines." " ${ }^{40}$ The contradictory statements of the Federal Circuit in Research Corp. and Prometheus suggest that the role of the machine-or-transformation test will be at least subject to ongoing debate.

\section{The Perils of the Machine-or-Transformation Test}

The machine-or-transformation test is problematic. It contains a number of ambiguities, leads to some bizarre results, and poorly tracks the stated goal of preventing the patenting of abstract ideas.

First the ambiguities. Does the machine-or-transformation test apply only to process claims? The prior Supreme Court cases in Benson, Flook, and Diehr were all process claims. ${ }^{41}$ The Federal Circuit decision in In re Bilski distinguishes In re Nuijten as directed to an article of manufacture, not a process, ${ }^{42}$ but does not do the same for In re Alappat, an en banc decision holding that a new computer program automatically makes a general-purpose computer "a new machine." 43 The BPAI and the district courts have generally held that the machine-or-transformation test is not limited to process claims. And there is no logical reason to cabin the holding to process claims; Benson and Diehr were process claims, but the Court's analysis did not focus on that fact. If the machine-or-transformation test were limited to process claims, it would generally

39. 628 F.3d 1347 (Fed. Cir. 2010).

40. Id. at 1355 (alteration in original) (emphasis added) (quoting Bilski v. Kappos, 130 S. Ct. 3218, 3227 (2010)) (some internal quotation marks omitted).

41. See infra Part II.D.2.

42. See In re Bilski, 545 F.3d 943, 951 n.2 (Fed. Cir. 2008) (en banc). The court dodged the question about whether Nuijten's process for creating signals sufficed.

43. In re Alappat, 33 F.3d 1526, 1545 (Fed. Cir. 1994) (en banc); see In re Bilski, 545 F.3d at 958-60. 
be easy to draft around; most computer-implemented process claims can be rewritten as a machine or article of manufacture claims. ${ }^{44}$

Second, is a general-purpose computer a "specific machine," as per Alappat? The Federal Circuit expressly reserved this question in In re Bilski. ${ }^{45}$ If it is, Bilski arguably invalidates tens of thousands of existing patents but will be easy to draft around in the future. But it would be a bit odd to say that Bilski's hedging method becomes patentable if he adds "in a computer" at the end. The BPAI has mostly (and the district courts have unanimously) read Bilski to say that a general-purpose computer is not enough, though patent examiners have reportedly been more forgiving of such claims. ${ }^{46}$

If these ambiguities are resolved — as they seem to have been so far-by concluding that you cannot evade the machine-or-transformation test by adding the phrase "in a computer" or by redrafting the claim as a system claim, the machine element of the machine-or-transformation test appears to be quite restrictive. That in turn leads to some bizarre results. It will lead to efforts to draft claims to software run on specific machines, but-since the computer used is irrelevant in most software patents-patentees may try to write dozens of claims, each to a specific "machine” implementing their program. If that works, owners of existing patents will find their claims invalid because they didn't use the "magic words," 47 but going forward the strategy may allow patentees to approximate the effect of claiming their software on a general-purpose computer. If it doesn't work, the law will be drawing artificial distinctions between programs of equivalent inventiveness. For example, it seems pointless to say that the same software invention is patentable if it works only in an MRI machine but unpatentable if otherwise-identical software can be run on a PC.

At the same time, application of that rule seems underinclusive. Suppose we write a new song. ${ }^{48}$ Can we patent it? Not as such, but arguably the song could pass the machine-or-transformation test if we record it using an iTunes codec and claim it as a method implemented digitally on an MP3 player. After all, the song is claimed only on particular machines specially designed for that purpose. ${ }^{49}$ How about the arbitration process in Comiskey ${ }^{50}$ Does it really be-

44. A process that is implemented in a computer can be claimed either as a process or as a computer system that is programmed to perform the steps of the process. Only the form has changed.

45. See 545 F.3d at 962 ("We leave to future cases the elaboration of the precise contours of machine implementation, as well as the answers to particular questions, such as whether or when recitation of a computer suffices to tie a process claim to a particular machine.”).

46. See supra note 33 and accompanying text.

47. Cohen \& Lemley, supra note 8, at 9 (describing the "doctrine of the magic words").

48. Don't worry, we haven't.

49. Cf. In re Alappat, 33 F.3d 1526, 1554 (Fed. Cir. 1994) (Archer, C.J., concurring in part and dissenting in part) ("Through the expedient of putting his music on known structure, can a composer now claim as his invention the structure of a compact disc or player piano 
come patentable if run on a particular computer? We are confident that the adopters of the machine-or-transformation test didn't intend those results. A specific machine seems an unnecessary limitation in some cases, and an insufficient one in others. The reason is the same in both cases: the test is focusing on the tail (the prior art machine with which the new invention works) and ignoring the dog (the new invention itself).

Application of the transformation prong of the machine-or-transformation test produces even more bizarre results. What does it mean to transform something "to another state or thing"? The Federal Circuit in In re Bilski expressly rejected the idea from Comiskey that physical steps are required. ${ }^{51}$ But it also seemed to reimport that limitation by talking about machines or transformations of articles. The result is ambiguity whether a physical thing, or merely a relationship among things, needs to be transformed. Is FedEx patentable subject matter because packages are moved from place to place, or must the packages themselves be changed? Is a method of swinging a golf putter transformative because it results in a golf ball being moved to a different place than it otherwise would have been $?^{52}$

The Federal Circuit decision in In re Bilski suggests-mostly-that transformation requires some physical change to the patented thing itself. The Supreme Court language from which it is taken, after all, speaks of "[t]ransformation and reduction of an article to a different state or thing." Carving wood into a chair "transforms" it into a new thing-a chair. Chemical reactions change the state of the chemicals involved. But there remains the problem of whether the transformation is sufficient, especially with respect to process claims.

Unfortunately, the analysis becomes even more confusing. Despite the preference for physical transformation, the Federal Circuit in In re Bilski (in its oddest passage) concludes that transforming data itself can meet this test in certain circumstances. Citing Abele, the court distinguishes between invalid general claims to outputting data results and valid specific claims to outputting particular data made using a particular machine. ${ }^{54}$ The court endorses the latter as long as the data "represents physical objects or substances." 55 The machine is the same, the transformation is the same-a computer has different bits set than it otherwise would, which means that the electrical impulses across gates on its

roll containing the melody he discovered and obtain a patent therefor? The answer must be no.”).

50. See In re Comiskey, 499 F.3d 1365, 1368 (Fed. Cir. 2007).

51. See In re Bilski, 545 F.3d 943, 960-61 (Fed. Cir. 2008) (en banc).

52. Cf. Gerard N. Magliocca, Patenting the Curve Ball: Business Methods and Industry Norms, 2009 BYU L. REV. 875, 876 (describing the throwing of a curve ball as transformative).

53. Gottschalk v. Benson, 409 U.S. 63, 70 (1972) (internal quotation marks omitted).

54. See In re Bilski, 545 F.3d at 963.

55. Id. 
chips are in a different array. But to the Federal Circuit the result is transformative if, but only if, the data these bits refer to represents a physical thing. Kevin Collins has referred to this as meta-tangibility: the question is not whether the invention is tangible, but whether the intangible invention refers to something that is itself tangible. ${ }^{56}$

Coal (the subject of the contracts in Bilski) is plainly a real-world physical thing. Would claim 1 in Bilski survive if it added a reference to the physical thing that was the subject of the contract? If an algorithm can only be used in a computer (as in Benson), does displaying the results from that algorithm render the invention patentable? This approach makes no sense. As with the machine prong, the transformation test is not focused on the invention, but on something external to it.

The Federal Circuit created this meta-tangibility data transformation exception to explain the result in In re Abele. ${ }^{57}$ That case held that a narrow claim directed to a program that displayed the results of a CAT scan was patentable subject matter, but that a broad claim that purported to patent the use of a calculation to shade display images was not. ${ }^{58}$ But as described in In re Bilski, the distinction is illogical.

To presage our argument in Part II, the real issue in Abele is not whether the information being displayed relates to something physical. The issue is overclaiming. Tailored claims should survive even if they aren't transforming anything physical, but broad claims that encompass any sort of data shouldn't. But that's not the way it works under the machine-or-transformation test. If we hope to limit patentable subject matter in a predictable and rational way, the machine-or-transformation test is not the way to do it. In the next Part, we introduce our alternative.

\section{The TheORY OF SubJeCt MATter Restrictions}

Patent eligibility requires that the subject matter clear two primary hurdles. First, each claim must fall within one of the statutory buckets: process, machine, manufacture, or composition of matter. ${ }^{59}$ These groupings are categorical-either a claim falls within the statute or it does not.

Second, each claim must fall outside of one of the common law exceptions: abstract ideas, laws of nature, and natural phenomena. ${ }^{60}$ It is here that Bilski and its predecessors are the most opaque: each case purports to grant or deny

56. See Kevin Emerson Collins, An Initial Comment on In re Bilski: Tangibility Gone Meta, PATENTLY-O BLOG, 1 (Nov. 1, 2008), http://www.patentlyo.com/patent/law/ collinsmetabilski.pdf.

57. See In re Bilski, 545 F.3d at 962-63.

58. See In re Abele, 684 F.2d 902, 908 (C.C.P.A. 1982).

59. See 35 U.S.C. § 101 (2006).

60. See Bilski v. Kappos, 130 S. Ct. 3218, 3225 (2010). 
eligibility to a particular patent claim, but fails to provide guidance about how to handle the next claim. ${ }^{61}$ Bilski makes clear that while the Supreme Court has no intention of abandoning these old exceptions, neither does it intend to provide further guidance. Perhaps even worse, the guidance we have from the machine-or-transformation test isn't helping. A principled theory is needed.

\section{A. Prior Subject Matter Theories}

The traditional way academics think about patentable subject matter is as a gatekeeper: a means of excluding certain types of inventions entirely from the scope of patent protection. ${ }^{62}$ Gatekeeping approaches have proven unsatisfactory. While they may serve to reduce administrative and judicial costs in determining eligible subject matter, gatekeeping theories are necessarily bright-line rules: they will both exclude some patents that should be granted and fail to exclude others that should not. We think this unwise. The core mission of patent law is to create incentives for the production, disclosure, and commercialization of socially valuable inventions. The flexibility of any subject matter requirement is paramount given the rapidly changing nature of technology. For example, prior to Bilski, the Court last considered the scope of patentable subject matter in 1981, based on inventions made nearly a decade earlier. ${ }^{63}$ At the time those inventions were made, the biotechnology and personal computer industries were just starting, there was no such thing as a cell phone, and the Internet was something used by only a few computer scientists at universities. Had the Court created an inflexible rule in 1981 governing the patentability of software or communications technologies from 1970, that rule could have had a range of

61. See generally Michael Risch, Everything Is Patentable, 75 TEnN. L. Rev. 591, 649 (2008) (noting that current subject matter rules "cannot be applied narrowly").

62. See, e.g., Kevin Emerson Collins, Claims to Information Qua Information and a Structural Theory of Section 101, 4 I/S: J.L. \& POL’y FOR INFO. SOC’y 11 (2008); Kevin Emerson Collins, Propertizing Thought, 60 SMU L. REV. 317 (2007); Kevin Emerson Collins, Semiotics 101: Taking the Printed Matter Doctrine Seriously, 85 IND. L.J. 1378 (2010); Jay Dratler, Jr., Does Lord Darcy Yet Live? The Case Against Software and BusinessMethod Patents, 43 Santa Clara L. Rev. 823 (2003); Robert A. Kreiss, Patent Protection for Computer Programs and Mathematical Algorithms: The Constitutional Limitations on Patentable Subject Matter, 29 N.M. L. REV. 31, 86-87 (1999); Menell, supra note 20, at 1312-13 (arguing that patents should be limited to the technological arts); David S. Olson, Taking the Utilitarian Basis for Patent Law Seriously: The Case for Restricting Patentable Subject Matter, 82 Temp. L. Rev. 181, 184 (2009); Pamela Samuelson, Benson Revisited: The Case Against Patent Protection for Algorithms and Other Computer Program-Related Inventions, 39 EMORY L.J. 1025, 1042-43 (1990); Pamela Samuelson \& Jason Schultz, "Clues" for Determining Whether Business and Service Innovations Are Unpatentable Abstract Ideas, 15 LEWIS \& CLARK L. REV. 110 (2010) (arguing that business methods should generally be unpatentable despite Bilski); John R. Thomas, The Patenting of the Liberal Professions, 40 B.C. L. REv. 1139 (1999); Joshua D. Sarnoff, Patent Eligible Inventions After Bilski: History and Theory (Feb. 07, 2011) (unpublished manuscript), available at http://papers.ssrn.com/sol3/papers.cfm?abstract_id=1757272.

63. See Diamond v. Diehr, 450 U.S. 175 (1981). 
unintended consequences, preventing the patenting of important new inventions in a wide range of fields. Quite simply, innovation in industry must necessarily include innovation in applied processes.

Furthermore, gatekeeping rules don't have very clear lines; ${ }^{64}$ subject matter category delineation is notoriously elusive. There is no clear division between "software" and "nonsoftware" patents, or a computer system that implements a "business method" and one that implements another type of process, or between "technological" and "nontechnological" inventions. Lack of rigidity is not inherently bad; we suggest a flexible, factors-based test ourselves. But because gatekeeping rules attempt to draw conceptual lines around classes of technology with unclear boundaries-instead of using the policy-based factors that should drive patentable subject matter determinations - the result is a set of tests that overexclude and underexclude in a costly and haphazard way.

One of us has gone so far as to argue that the best solution is to abandon all exceptions, including the historical ones. ${ }^{65}$ Whether or not this approach is correct, it is unlikely to gain judicial support in light of Bilski. Therefore, we take the common law abstract ideas exception as a given, and seek to articulate a reason to preclude patentability for abstract ideas and a corresponding way to recognize when patent claims are too abstract. We recognize that this better way has been elusive. Even those commentators who agree that the abstract ideas exception is a scope limitation device fail to provide a principled way to apply the standard. ${ }^{66}$ Instead, they usually rely on $\S 112$ of the Patent Act, conflating overbreadth for patentable subject matter purposes with enablement and written description. ${ }^{67}$

64. Even the categories in the Patent Act are sometimes difficult to apply. See, e.g., Am. Fruit Growers, Inc. v. Brogdex Co., 283 U.S. 1, 10-13 (1931) (determining whether an orange dipped in borax is a "manufacture"); In re Nuijten, 500 F.3d 1346, 1353-57 (Fed. Cir. 2007) (determining whether an electrical signal falls into a statutory category).

65. See Risch, supra note 61, at 591.

66. For example, T.J. Chiang argues that patentable subject matter encompasses both gatekeeping and scope limitations, and suggests that the abstract ideas exclusion is primarily a scope limitation. Tun-Jen Chiang, The Rules and Standards of Patentable Subject Matter, 2010 Wis. L. REV. 1353, 1363, 1381. He does not, however, attempt to articulate the scopelimitation analysis. For other scope-related theories of patentable subject matter, see, for example, Efthimios Parasidis, A Uniform Framework for Patent Eligibility, 85 TuL. L. ReV. 323, 387-89 (2010); Jur Strobos, Stalking the Elusive Patentable Software: Are There Still Diehr or Was It Just a Flook?, 6 HARV. J.L. \& TECH. 363, 365 n.8 (1993); Bryan Treglia, Separating Abstract Ideas and Laws of Nature from Patentable Subject Matter, 48 JURIMETRICS J. 427, 434-37 (2008).

67. See, e.g., Donald S. Chisum, Weeds and Seeds in the Supreme Court's Business Method Patents Decision: New Directions for Regulating Patent Scope 8-10 (Oct. 27, 2010) (unpublished manuscript), available at http://ssrn.com/abstract=1698633. 


\section{B. Abstract Ideas as Scope Limitation}

We start with the unremarkable observation that the statutory categories outlined in $\S 101$ - process, machine, manufacture, and composition of matter"-are of relatively limited usefulness in analyzing whether a patent claim falls within patentable subject matter. Indeed, because patent claims almost never fall outside of the four fundamental categories of $\S 101$, when they do it is noteworthy. For example, in In re Nuijten, the Federal Circuit held that an electrical signal alone - not tied to any storage or transmission medium-did not fall within any of the categories. ${ }^{68}$ We might also think of the per se bars against claims that encompass laws of nature and no more, like gravity and relativity, as similar in kind: such claims are not patentable subject matter because, without more, they are usually not processes, machines, manufactures, or compositions of matter. By contrast, there is no per se bar to patenting laws of nature as applied in a process, machine, manufacture, or composition of matter. As a general matter, the traditional examples of barred subject matter are typically the easy cases. The harder (and more pressing) question is how to analyze claims falling within the statutory categories.

This is the role for the common law exceptions to patentable subject matter: excluding, for policy reasons, claims to subject matter irrespective of their categorical status. And in order to appropriately apply the exceptions, one must first understand their theory and the particular policy problem they are addressing.

In our view, the abstract ideas exception is directed to an inherent tension between two major policy goals of the patent system. First, inventors should be entitled to claim all that they have actually invented (or at least all that they have taught to the world via their patent disclosure) - thereby implementing the incentive structure that lies at the heart of the patent grant. Limiting inventors to the particular machine they developed would make patents a "hollow and useless thing." 69 Second, we want to further the progress of society by continually growing the storehouse of knowledge. In some cases, these goals can be in substantial tension-particularly where a patentee's claimed invention would curtail access to ideas that are in essence reserved to society.

But what ideas are reserved to society? Those that are fundamental, the building blocks of human thought: "A principle, in the abstract, is a fundamental truth; an original cause; a motive; these cannot be patented, as no one can claim in either of them an exclusive right.. ${ }^{, 70}$ Importantly, patentees can and

68. 500 F.3d at 1351, 1353. Even that conclusion was questionable as a matter of physics and statutory interpretation. John F. Duffy, In re Nuijten: Patentable Subject Matter, Textualism and the Supreme Court, PAtently-O Blog (Feb. 5, 2007), http://www.patentlyo.com/patent/DuffyOnNuijten.pdf. Even so, the policy consequences of holding that a signal is "made" whenever it passes through a wire would have been dire.

69. Graver Tank \& Mfg. Co. v. Linde Air Prods. Co., 339 U.S. 605, 607 (1950).

70. Le Roy v. Tatham, 55 U.S. (14 How.) 156, 175 (1853). 
often do employ abstract ideas or scientific principles to a useful and practical end, and when they do they are entitled to a patent. The worry is not that an inventor controls the application of an abstract idea, but only that an inventor obtains rights over the idea itself. That is, the abstract ideas exception operates where a patent claim is "too broad" in the sense that it encroaches upon society's right to unfettered access to scientific truths, fundamental principles, and the like; these properly belong in the commons upon which future innovations can be built, "free to all men and reserved exclusively to none."71

This concern about overbreadth is not, we think, limited to the abstract ideas doctrine; it also animates the prohibition against patenting products of nature. Here, the law has repeatedly emphasized that the patent law is designed to protect applications of human ingenuity, not simply "nature's handiwork.",72 Thus, while a man-made organism is eligible for patentability, ${ }^{73}$ a natural bacterium is not. ${ }^{74}$ But natural products or phenomena can be patented when they are put to a specific new use. The boundary is neither the form of the invention nor its ability to "transform" nature; instead the analysis turns on whether the patent claims describe the application of human knowledge to a practical end, rather than merely identification of the existence of useful properties. In this way, a claim to an abstract idea is like a claim to a product of nature: not limited to real-world applications of human inventiveness, and thus ineligible for patenting.

Understood in this way, the abstract ideas doctrine is not about finding a conceptual category of inventions that is entitled to no protection at all, nor about determining the quality of the disclosure. Instead, it is about encouraging cumulative innovation and furthering societal norms regarding access to knowledge by preventing patentees from claiming broad ownership over fields of exploration rather than specific applications of those fields. Boiling these principles down to a practical test is a more difficult task. The abstract ideas exception should disallow those claims to ideas unmoored to real-world applications, taking into account the extent to which the claim forecloses after-arising embodiments of the idea, the nature and extent of the prior art, and the level of disclosure by the inventor.

\section{Distinguishing the Scope Limitations in $\S 101$ and $\S 112$}

Patent law has other doctrines that limit the scope of claims. Section 112 requires that a patentee claim no more than she has described in writing and

71. Funk Bros. Seed Co. v. Kalo Inoculant Co., 333 U.S. 127, 130 (1948).

72. Diamond v. Chakrabarty, 447 U.S. 303, 310 (1980); see also Funk Bros., 333 U.S. at 131 .

73. See Chakrabarty, 447 U.S. at 310.

74. See Funk Bros., 333 U.S. at 131. 
taught others how to make and use. ${ }^{75}$ But overbreadth as a limitation on a patentable subject matter differs in motivation and effect from scope limitations imposed under $\S 112$.

First, $\S 112$ merely examines whether the disclosure is sufficient to warrant the claims. ${ }^{76}$ While some claims may be too broad in light of the disclosure, they are not necessarily abstract ideas. ${ }^{77}$ Relatedly, enablement does not provide enough of a limitation on scope as the level of skill in the art goes up. ${ }^{78}$ Overclaiming under $\S 101$, on the other hand, is primarily concerned with removing obstructions to follow-on innovation. The question is not whether one could make the embodiments claimed, but rather whether the inventor has contributed enough to merit a claim so broad that others will be locked out. ${ }^{79}$

Removing certain inventions-particularly inventive principles-from patentability diminishes burdens to follow-on inventors who might make use of those principles in new embodiments or applications of the principle. If we allowed exclusionary rights over broad principles, later inventors wanting to employ those principles in new inventions would need to license rights to the original patent, thereby increasing the costs to follow-on invention. The precise level of "abstractness" of a given claim at which follow-on invention is overly burdened is somewhat arbitrary. ${ }^{80}$ Nonetheless, when a patent claim would foreclose all future embodiments or applications of the inventive principle claimed in a patent, courts have balked. That is true even if the patentee has enabled others to use all currently known embodiments, thus satisfying $\S 112$. In the words of the Supreme Court, such claims "wholly pre-empt” all present and future uses of the inventive principle. ${ }^{81}$

Second, the enablement and written description requirements of § 112 concern the adequacy of the inventor's disclosure at the time of filing. Scope concerns under $\S 101$, however, relate to the possibility of invention after filing. Indeed, under $\S 112$, as long as an inventor sufficiently discloses those embo-

75. See 35 U.S.C. § 112 (2006).

76. See The Incandescent Lamp Patent, 159 U.S. 465, 474 (1895) (holding that claim to light filaments made from any carbonized textile or vegetable fiber was too broad in light of disclosure that described only one type of fiber).

77. See, e.g., id. While the filament claims were broader than the disclosure allowed, they were not abstract.

78. See Dan L. Burk \& Mark A. Lemley, Is Patent Law Technology-Specific?, 17 BERKELEY TECH. L.J. 1155, 1164-65 (2002) (arguing that judicial attribution of high skill level to programmers has nullified enablement requirement for software patents); Michael Risch, A Brief Defense of the Written Description Requirement, 119 Yale L.J. ONLINE 127, 138-39 (2010) (arguing that description is critical because high skill means more claims with less disclosure of actual invention).

79. One of the authors has argued that we could accomplish the same end with a more capacious understanding of $\S 112$. Risch, supra note 61 , at 591 . But we currently do not have such an understanding.

80. See infra Part III.

81. Bilski v. Kappos, 130 S. Ct. 3218, 3230 (2010) (quoting Gottschalk v. Benson, 409 U.S. 63, 72 (1972)). 
diments of the invention that could have been built at the time of filing, the inventor will generally be afforded exclusionary rights over later inventions that use after-arising technology - technology that did not exist at the time of filing. Section 101, on the other hand, concerns itself precisely with the degree to which a patent claim will foreclose later-developed technology. Thus, even an inventor meeting the requirements of $\S 112$ may write a claim so broad as to violate $\S 101$. This distinction in timing is critical to understanding the differences in patent scope thresholds under the two sections.

By removing overly abstract inventions from patenting, we drive more competition in research and development races to complete practical, applied inventions. In other words, by moving patenting downstream, we both permit competition in research and development and encourage competition among the practical, applied inventions developed by that research. ${ }^{82}$ Thus, by limiting claims to practical applications, as opposed to broadly claimed abstract inventions, we help promote the goal of stimulating optimal invention. Section 112 may have the prevention of gun jumping as a subsidiary goal, but an overclaiming view of $\S 101$ puts the primary focus on whether the claims reflect an applied principle.

Finally, the enablement inquiry itself is extremely difficult and fraught with contradiction. ${ }^{83}$ Our focus under $\S 101$ on claim scope with an eye toward practical application provides for a different type of analysis. It may be that claims are not abstract but also not enabled (like Incandescent Lamp) or it may be that claims are abstract, but enabled (like Benson).

Similarly, definiteness concerns under $\S 112$, paragraph 2, inform but do not replace our standard. Definiteness asks whether a person having ordinary skill in the art (PHOSITA) could understand the claims, regardless of how abstract or applied they might be. Bilski’s claim to hedging was understandable, even if it was overbroad. Under $\S 101$, we are concerned about the uncertainty and vagueness of claims over abstract ideas or natural laws that could thwart optimal invention by closing off avenues not invented (or inventible) by the patentee. Claims that are indefinite under $\S 101$ may be clear in their language but

82. See Christopher A. Cotropia, The Folly of Early Filing in Patent Law, 61 HASTINGS L.J. 65, 127 (2009) (arguing that inventions should be reduced to practice to improve commercialization); see also Michael Risch, Reinventing Usefulness, 2010 BYU L. REV. 1195, 1224-34 (discussing practical utility as a commercialization lever); Ted Sichelman, Commercializing Patents, 62 STAN. L. REV. 341, 343 (2010) (discussing incentives provided by patent law to commercialize inventions).

83. See, e.g., T.J. Chiang, The Levels of Abstraction Problem in Patent Law, 106 Nw. U. L. REV. (forthcoming 2011) (manuscript at 6), available at http://papers.ssrn.com/sol3/ papers.cfm?abstract_id=1434465 (noting that determining whether a claim is enabled requires us to choose the level of abstraction at which we assess that claim); Timothy R. Holbrook, Patents, Presumptions, and Public Notice, 86 InD. L.J. (forthcoming 2011) (manuscript at 18-19), available at http://ssrn.com/abstract=1650819; Jeffrey A. Lefstin, The Formal Structure of Patent Law and the Limits of Enablement, 23 BERKELEY TECH. L.J. 1141, 1168 (2008). 
still lead to indeterminate results because they claim activities that are not under the control of the person practicing the method. ${ }^{84}$

\section{Scope Limitation in the Case Law}

In our view, the theory articulated here explains most of the major cases implementing the $\S 101$ abstract ideas exception.

\section{Historic cases}

Three historic cases illustrate how excluding abstract ideas limits claim scope. In O'Reilly v. Morse, the Supreme Court considered Samuel Morse's patent on the telegraph. ${ }^{85}$ It allowed what many would consider today to be a business method claim: "the system of signs, consisting of dots and spaces, ... . in combination with machinery for recording them, as signals for telegraphic purposes." ${ }^{\prime 86}$ It also allowed Morse’s claim to his particular telegraph. However, the Court denied Morse's claim to all transmission of printed information by an electromagnetic signal by any means. ${ }^{87}$ While the Court had no problem with patenting a particular form of such transmission - the telegraph—it invalidated the broader claim because Morse claimed all forms of printing at a distance without tying the claim to any process or machinery disclosed in the patent. $^{88}$

It is no surprise that many consider Morse to be an enablement case. ${ }^{89}$ But this explanation is incomplete, because the Court's ruling goes beyond ordinary application of enablement. The Court's concern is not just undue experimentation necessary to achieve the broad claim scope. ${ }^{90}$ Nor can the case solely be explained on the grounds of the written description doctrine. ${ }^{91}$ Although the Court stated that Morse "claims an exclusive right to use a manner and process

84. There may also be distributive concerns in $\S 101$ analysis: subject matter jurisprudence consistently recites that certain principles must be "free to all men." Funk Bros. Seed Co. v. Kalo Inoculant Co., 333 U.S. 127, 130 (1948). This language is not present in enablement and definiteness cases.

85. 56 U.S. (15 How.) 62 (1854).

86. Id. at 86.

87. See id. at 112-17.

88. See id. at 113; see also id. at 118-19 (describing the importance of description of the patented invention).

89. See, e.g., Craig Allen Nard, The Law of Patents 51 (2008) (presenting Morse at the beginning of a patent textbook section on enablement).

90. Cf. The Incandescent Lamp Patent, 159 U.S. 465 (1895) (holding that enablement is based on undue experimentation); In re Wands, 858 F.2d 731, 737 (Fed. Cir. 1988) (describing factors to consider for undue experimentation in enablement).

91. Cf. Ariad Pharm., Inc. v. Eli Lilly \& Co., 598 F.3d 1336, 1346 n.4 (Fed. Cir. 2010) ("Morse, decided under the 1836 Act, can also be interpreted as involving a separate written description inquiry.”). 
which he has not described," it goes further by stating Morse's claim would foreclose "future inventor[s]" who "may discover a mode of writing or printing at a distance by means of the electric or galvanic current," that is, after-arising technology. ${ }^{92}$

Written description-like enablement-is measured at the time of filing. Thus, even claims that meet the written description requirement will generally foreclose "future inventors" who find new "means" of implementing the claimed invention, particularly for complex inventions composed of many separate components, any one of which might be replaced by after-arising technology that still falls within the literal scope of the claim language. Thus, the concern about follow-on invention in Morse cannot merely be explained by standard disclosure doctrines. Morse had, after all, taught the only way known at the time to use magnetism to print characters at a difference, so arguably he had satisfied the enablement standard as we understand it today. Instead, the Court's concerns require a separate theory of scope, one premised on patent eligibility of overly abstract claims.

In contrast with Morse's claim is Bell's patent on the telephone, which was upheld in the Telephone Cases. ${ }^{93}$ Bell discovered that voice could be transmitted over a closed circuit by varying the amplitude of the electrical signal; this discovery solved a problem that inventors attempting to transmit voices by opening and closing circuits (like the telegraph) could not solve. Bell, however, was a prophetic inventor who did not complete a working embodiment before he applied for his patent. ${ }^{94}$ Indeed, he only described one embodiment of his broad claims. Further, though Bell claimed two ways to transmit speech-the vibration and the variable resistance method - the device he described would only use one of the two ways, the vibration method. ${ }^{95}$ And Bell did not describe how to make a device to practice the other way. ${ }^{96}$

Nonetheless, the Court allowed a claim to the broad process of sending voice using either the vibration or the variable resistance method. The Court focused not on Bell's failure, but on the practical use of his principle. ${ }^{97}$

The Telephone Cases also mix concerns of disclosure under the enablement doctrine with concerns about follow-on invention. Whether Bell provided sufficient disclosure to support his claim is a question of enablement-and, perhaps, in modern parlance, of written description. But whether the claim was sufficiently specific - here, claiming a "practicable way of putting [the principle] into operation"98_is a $\S 101$ overbreadth issue, because the specificity

92. Morse, 56 U.S. (15 How.) at 113.

93. 126 U.S. 1 (1888).

94. See id. at 535.

95. See id. at 538.

96. See id.

97. See id. at 536.

98. Id. 
of the claim affects the latitude with which follow-on invention may be undertaken.

In this latter respect, the Court made two important statements. First, the Court noted that Bell was not claiming more than a very specific application of the principle that he invented: "Both forms of apparatus operate on a closed circuit by gradual changes of intensity, and not by alternately making and breaking the circuit . . .."99 Second, the Court noted that the general principle of gradual electrical changes provided a specific, applied solution that was not available before. ${ }^{100}$

Bell was entitled to the general and broad method that he discovered because he was able to describe "the exact electrical condition that must be created to accomplish his purpose."101 The Court distinguished this from Morse's unapplied claim to all electromagnetic transmissions by any means:

It may be that electricity cannot be used at all for the transmission of speech except in the way Bell has discovered, and that therefore, practically, his patent gives him its exclusive use for that purpose, but that does not make his claim one for the use of electricity distinct from the particular process with which it is connected in his patent. ${ }^{102}$

Here, too, the question is whether Bell attempted to claim more than a new, specific, practical, and applied benefit. The Court said no-the specific solution to a specific problem might have broad application, but it was an application of the inventive principle. Other inventors remained free to investigate other ways of communicating voice over an electric wire because Bell did not claim all transmissions of voice by any means or machinery.

A third example is Mackay Radio, in which a well-known equation predicted the optimal wire lengths for receiving radio signals. ${ }^{103}$ The patentee (who did not discover the equation) claimed an antenna using these lengths. The Supreme Court held that the antenna was a patent-eligible application of the equation: "While a scientific truth, or the mathematical expression of it, is not patentable invention, a novel and useful structure created with the aid of knowledge of scientific truth may be."104 The Court made clear that claim scope was the key factor in determining whether the antenna was patentable, and that the application of a known principle would be narrowly construed. ${ }^{105}$

Mackay illustrates two fundamental points in our theory. First, practical applications of so-called "abstract ideas" are patentable. Second, consideration of a claim's contribution to applied uses is a matter of claim scope. Applying a

99. Id. at 538.

100. See id. at 544 .

101. Id. at 535.

102. Id.

103. Mackay Radio \& Tel. Co. v. Radio Corp. of Am., 306 U.S. 86, 93-94 (1939).

104. Id. at 94 .

105. See id. 
basic scientific principle to the construction of a useful object is patentable; claiming every use of that principle isn't.

\section{Modern Supreme Court cases}

Our scope theory is also largely consistent with the Court's more recent "abstract idea" decisions. In Gottschalk v. Benson, the Court invalidated a claim to a process for converting binary coded decimal numbers into pure binary format. ${ }^{106}$ The method was well-known, and could be done by pencil, but had not been implemented by computer. ${ }^{107}$ The process claim, the Court ruled, was simply too broad and untied to any application, especially in comparison to the contribution of the inventor: "Here the 'process' claim is so abstract and sweeping as to cover both known and unknown uses of the BCD to pure binary conversion. The end use may . . . be performed through any existing machinery or future-devised machinery or without any apparatus." ${ }^{108}$ In short, whatever was new about the invention was unmoored to any practical application, such that it was "so abstract and sweeping" as to unduly foreclose follow-on invention, particularly that using after-arising technologies. Given the Court's concern with "unknown uses" and "future-devised machinery," Benson cannot merely be explained by traditional scope and disclosure doctrines.

Nor are technology-driven explanations of Benson as rejecting all claims involving software or mathematical algorithms satisfying. For just nine years later in Diamond v. Diehr, without repudiating Benson, the Court upheld a process for curing rubber even though the process incorporated a well-known mathematical formula about how long to cure rubber. ${ }^{109}$ Diehr is a straightforward application of our theory-Diehr's process was tied to a specific practical application of the formula that did not unduly foreclose future innovation relying on the formula.

Even the outcome, though not the methodology, in the troublesome case of Parker v. Flook ${ }^{110}$ might be explained by our theory. In Flook, the Court ruled that a claimed method for updating an alarm limit in catalytic conversion using a specified algorithm was unpatentable under $\S 101 .^{111}$ The problematic aspect of the case is its apparent reliance on "point of novelty" analysis - treating the mathematical algorithms that were the novel feature of the invention as if they were already known. This approach is problematic in many respects, ${ }^{112}$ and for that reason it is tempting to dismiss the case as an outlier. Indeed, the Court's

106. 409 U.S. 63,65 (1972).

107. See id. at 67.

108. Id. at 68 .

109. 450 U.S. 175 , 187 (1981).

110. 437 U.S. 584 (1978).

111. Id. at 594 .

112. See, e.g., Mark A. Lemley, Point of Novelty, 106 Nw. U. L. REv. (forthcoming 2011), available at http://ssrn.com/abstract=1735045 (critiquing this aspect of Flook). 
holding on point of novelty was essentially overruled a few years later in Diehr. ${ }^{113}$

Despite its doctrinal problems, the outcome in Flook can be understood as consistent with our theory. The inventor claimed a general method of calculating "alarm limits" in a catalytic conversion process. ${ }^{114}$ The process, however, did not purport to measure temperature, pressure, volume, or any other specific aspect of the catalytic conversion process. Thus, the claim was not tied to any application whatsoever. Yet the patent applicant wanted to bar all uses of the formula in any later application of it. Read this way, the Flook Court merely found that the patent applicant was claiming too broadly. The Court's analysis revealed that Flook's claim far exceeded — and indeed Flook never demonstrated-any real-world practical application, wholly preempting all present and future uses of the alarm-limit algorithm not only in catalytic conversion, but potentially elsewhere. Such a broad claim is properly barred by the abstract ideas exception.

The Court's rejection of Bilski's claimed method of hedging is consistent with our theory. The patent application in Bilski described a very specific way to use historic weather data to determine optimal prices for hedging transactions in particular commodities. ${ }^{115}$ Yet the first claim sought to patent all such hedging transactions, at any price, for any commodity. ${ }^{116}$ Like the other patent applicants outlined here, Bilski claimed too broadly-effectively seeking to control the idea of hedging, unmoored to the practical applications the inventor actually disclosed.

We do think this analysis points to a failing in the Court's Bilski opinion: it is too quick to reject each of the other claims. While close analysis may reveal that each of Bilski's narrower claims was still too broad, the Court gave short shrift to such considerations. It is possible that Bilski narrowed the dependent claims sufficiently to cover only a specific, practical, even novel application.

Finally, our theory provides the only reasonable explanation of the Federal Circuit's decision in In re Abele, ${ }^{117}$ which otherwise seems an outlier. In Abele, the applicants invented an improvement in digital x-ray data processing that allowed for better imaging while exposing patients to less radiation. ${ }^{118}$ The invention involved narrowing an x-ray beam in order to reduce exposure, and a companion method of calculating the image data to correct for the deficiencies caused by a narrower beam. ${ }^{119}$

113. 450 U.S. at 187.

114. See In re Flook, 559 F.2d 21, 22 (C.C.P.A. 1977), rev'd sub nom. Parker v. Flook, 437 U.S. 584 (1978).

115. See Brief Amici Curiae of 20 Law and Business Professors in Support of Neither Party at 31-32, Bilski v. Kappos, 130 S. Ct. 3218 (2010) (No. 08-964).

116. See Bilski, 130 S. Ct. at 3223-24.

117. 684 F.2d 902 (C.C.P.A. 1982).

118. See id. at 903.

119. See id. at 904. 
The case involved two claims. Claim 5 covered a "method of displaying data" using certain calculations. Claim 6 was the same as claim 5, but limited to specific x-ray attenuation data. ${ }^{120}$ The court rejected the broad claim 5 , but upheld the narrower claim 6 . This result cannot be explained by saying that the broad claim did not transform anything, while the narrow claim did. Claim 5 encompasses-without question-a specific way to process and display an image. If, however, one were to focus on the intangibility of the result it produces-images on a computer screen - then the x-ray related claim must also be an abstract idea. Those images are merely a subset of the images claimed in the broader claim, and processing x-ray data is no less abstract than processing other data. Nor can this result be justified by arguing-as the Federal Circuit does in formulating the machine-or-transformation test-that the data in claim 6 represents "physical" phenomena while the data in claim 5 does not. ${ }^{121}$ Claim 5 describes the display of a picture to which the data is related. A picture must necessarily be of something physical, so that the data must necessarily be related to something physical.

The best, and perhaps only, explanation for this result is that claim 5 was simply too broad. While claim 6 is grounded in a particular application with practical results relating to $\mathrm{x}$-ray technology, claim 5 is untethered to any specific application or technology. While the picture of claim 5 was physical in some sense, there is no limitation whatsoever on what the picture might be of. Thus, the claim effectively covers all uses of the algorithm to improve the image quality of the picture under consideration, foreclosing all present and future uses of the algorithm. Like the invalid claims in Morse, Benson, Flook, and Diehr, such broad claims are too abstract.

In short, we think the overclaiming approach is amply supported in the case law. The problem is that courts have not uniformly followed Diehr, nor have they explained the abstract ideas doctrine in a consistent and coherent way. The result has been that courts fall back on "clues" like the machine-ortransformation test that, even if based in a theory of overclaiming, disserve that goal in practice.

\section{A PROPER APPROACH TO IDENTIFYING CLAIMS THAT IMPERMISSIBLY COVER ABSTRACT IDEAS}

Focusing on claim scope provides a principled way to determine whether a particular claim, rather than a particular subject matter, is unpatentable. Specifically, our approach focuses on the application of the idea to determine the proper level of abstraction that merits protection. As claims become broaderand necessarily more general and abstract - they become more indefinite and difficult to understand, and more likely to ensnare future inventions embodying

120. See id. at 908 .

121. See In re Bilski, 545 F.3d 943, 962-63 (Fed. Cir. 2008) (en banc). 
the inventive principle. At their limit, they claim everything and contribute nothing. The practical effect of allowing such breadth is to make later improvements more costly or even impossible.

To be sure, identifying overclaiming is not straightforward, and no test will yield conclusive answers. Yet we believe some tests are clearly more workable - and better further the policy-based goals of § 101—than others. This Part discusses why the machine-or-transformation test is unsuitable, and then provides a better way to identify improper claims.

\section{A. The Failure of the Machine-or-Transformation Test}

As discussed in Part I, continued reliance on the machine-or-transformation test is problematic because that test has little to do with claim scope. For example, it fails to identify why the claims in Benson and Flook should be unpatentable when both are unambiguously performed by a machine. To be sure, the insignificant postsolution activity test provides an exception to the rule, but every software patent will be executed on a machine. If every such claim is reviewed for "insignificant" activity, the exception becomes the rule without any definition of what "insignificance" is.

A focus on physicality fares no better. For instance, the Federal Circuit held in Prometheus that the claimed medical diagnostic test sufficiently transformed matter, because "[t]he transformation is of the human body following administration of a drug."122 Chemical transformations that occur within the body, however, could just as plausibly be characterized as "insignificant extrasolution activity," because they simply relate to a mere "data-gathering step”123 that is tangential to the process performed directly by the diagnostic test. The court's conclusory reasoning about transformation does not answer the question; as Abele shows, a method may transform data about physical subject matter but still be too broad.

The problem is that the machine-or-transformation test simply asks the wrong question. For example, in Comiskey, the arbitration process was unpatentable not because it lacked a computer, but because the claim embraced countless arbitration arrangements untied to any practical application of their idea. The application claimed too much.

This is likely to be a recurring problem in software cases in particular. The genius of computer technology is that it is a platform that allows creation to occur on it. A computer program can be claimed in terms specific or general, but today (except by happenstance) it would rarely be logically limited to running on a particular type of hardware. Requiring that software claims be tied to particular machines would indeed impose a limitation on their scope, but the limi-

122. Prometheus Labs., Inc. v. Mayo Collaborative Servs., 581 F.3d 1336, 1346 (Fed. Cir. 2009), vacated and remanded, 130 S. Ct. 3543 (2010).

123. In re Bilski, 545 F.3d at 963. 
tation would bear no relationship to what the patentee actually invented. The first programmer to build a dynamic linked list shouldn't own the concept, and it doesn't help to say that he owns the concept when implemented on a Dell computer but not a Mac. Limiting the scope of a patent claim makes sense only if the limitation bears some relationship to the inventive aspect of the claimed invention. In software patents, hardware is almost never the inventive aspect.

Machines and transformations may be relevant to this inquiry, but only as a way to conceptualize whether a claim is overbroad. Treating machine-ortransformation as a proxy or other subpart of a gatekeeping test is ill-advised.

\section{B. Identifying Abstract Ideas}

Claims are proper when the scope of the patentee's claims is commensurate with a practical, real world contribution the patentee has made. They are too broad when they assert coverage over general ideas unmoored to any specific use, and therefore deprive subsequent researchers of access to those ideas. Make no mistake-determining whether claims are abstract must be performed case by case. Even so, courts and litigants need not be entirely at sea. We have rules (and standards) that guide us in determining whether a claim is enabled, novel, and so forth. Here, too, we have a baseline requirement: that the claim be tied to a practical, applied contribution of the inventor. The factors that follow are tools to answer this question, but the question itself is one that can have a principled answer.

One factor that courts should consider is the generative nature of the new technology. Is the claimed invention one with a very limited set of possible applications? If so, we might not worry about locking up future avenues of research. Patent claims to inventions that are ends in themselves, rather than means to new ends, are less likely to create $\S 101$ overbreadth problems. The Benson Court worried that the patentee would lock up the principle of binarycoded-decimal conversion. But the more specific a mathematical algorithm gets, the less likely it is to be useful outside the context of the patented invention. If Windows 7 is a mathematical algorithm (and in one sense, it is), it is not one we need worry much about preventing others from using for different ends. By contrast, the newer a field, and the more likely it is to have a variety of applications, the more reluctant we should be to award ownership of generative building blocks to people who have not yet explored how they may be applied.

Second, the nature of the industry in which the invention occurs may be relevant. While all inventors depend to some extent on the work of others, some industries are more likely to rely on cumulative innovation than others, and the danger of allowing patents on abstract claims is correspondingly greater in those industries. We think that explains why we have seen abstract idea cases almost exclusively in the electronic and computer arts, rather than in, say, the 
pharmaceutical industry. ${ }^{124}$ That is not to say a patentee could never overclaim in a mechanical art. Imagine, for instance, the inventor of the first catheter claiming "any means, however developed, for noninvasive surgical intervention in the human body." But the damage that such broad claims can do will be greater in industries that rely more heavily on cumulative innovation. ${ }^{125}$

Third, on a related note, industries differ in the speed with which advances are made. Because patents expire after twenty years, the cost of an overbroad patent claim may be less in a slow-moving field than in one that changes quickly. The Morse Court was prescient to suggest that eventually someone might happen upon other means than the telegraph of using electromagnetism to communicate at a distance, but as it happened, Morse's patent claims would have expired by the time the first of those new technologies was developed. But that will not always be the case, and in newer and faster-changing industries the risk of stifling after-arising technology is greater.

Fourth, courts should be particularly wary of general claims to a principle based on one or very few specific applications. When a patentee identifies only one specific application, but claims a very broad principle, it is more likely that the broader claim will encompass unanticipated applications. This situation increases the likelihood that others will need access to the claimed principle, access that might be denied or limited to the public's detriment. To be sure, written description and enablement analysis under $\S 112$ also examines such concerns; claims that are not described and enabled are also more likely to be abstract. When applied to abstract ideas, however, this factor can extend beyond $\S 112$. Because $\S 101$ is not tied to the filing date of the application, courts can consider potential (even hypothetical) technologies that might technically be enabled, but that are not supported by the application presented by the inventor. Further, § 112 sometimes permits patentees to claim a genus by relying on only a single example. While one example may enable one of skill in the art to practice a range of alternatives, $§ 101$ might still impose limits on the resulting claim.

Fifth, courts should consider the importance of the patentee's contribution. Strictly speaking, importance has no bearing on how abstract the patentee's claims are, but as we indicated earlier, overclaiming is about balancing the incentives needed for the patentee against the risk of stifling future innovation. Truly groundbreaking patents may require broader protection for the simple reason that an inventor who opens up a new field may have less idea how her invention will be used by others. We can't effectively assess that balance unless we have some sense of how important the patentee's invention is, as well as

124. See, e.g., Dan L. Burk \& Mark A. Lemley, The Patent Crisis and How the COURTS CAN SOLVE IT 142-66 (2009) (identifying abstract ideas doctrine as a policy lever that is likely to be more important in some industries than others).

125. The authors are not of one mind as to whether (and how much) courts should expressly consider the industry in deciding abstractness, but there is little question that abstract ideas claims will be more common in certain industries. 
how important the future innovation might be. An old doctrine once held that "pioneering" patents were to be given broad scope. ${ }^{126}$ That doctrine is now moribund, brought down by the singular focus on patent claim language to define an invention's scope. Yet the idea of pioneering patents might usefully be applied in this different context to give greater leeway to those who arguably teach more. The more important the patentee's contribution, the more we should err on the side of allowing broad claims at the margins. ${ }^{127}$

In sum, we believe at least five factors are critical to a proper scope-based determination for patentable subject matter eligibility under $\S 101$ :

- Is the claimed invention potentially generative of many kinds of new inventions?

- Does the industry rely heavily on cumulative invention?

- Is the technological field fast-moving?

- Has the patentee disclosed a small number of embodiments but claimed a broad inventive principle?

- Has the patentee made an important contribution relative to the prior art?

No one factor should dominate; we advocate a contextual, common-law approach. Courts and scholars are likely to develop other factors as our approach is applied over time.

\section{Overclaiming and the Decision Process}

Finally, thinking about $\S 101$ and the abstract ideas doctrine as scope limitations may help change the way we approach subject matter procedurally. The "gatekeeper" theory carries with it the logical consequence that $\S 101$ eligibility should be decided first. After all, if your invention isn’t eligible for patenting at all, we don't need to figure out whether it's new and nonobvious and whether you have taught people how to make and use it. And so the Federal Circuit in

126. See, e.g., Miller v. Eagle Mfg. Co., 151 U.S. 186, 207 (1894) ("If the invention is broad or primary in its character, the range of equivalents will be correspondingly broad, under the liberal construction which the courts give to such inventions.”); Perkin-Elmer Corp. v. Westinghouse Elec. Corp., 822 F.2d 1528, 1532 (Fed. Cir. 1987) (“A pioneer invention is entitled to a broad range of equivalents.”); John R. Thomas, The Question Concerning Patent Law and Pioneer Inventions, 10 HigH TECH. L.J. 35, 37 (1995) ("Courts construe pioneer patent claims ... to encompass a broader range of so-called 'equivalents' during an infringement determination.”).

127. See Kokomo Fence Mach. Co. v. Kitselman, 189 U.S. 8, 18-19 (1903) (“In view of what passed in the Patent Office, and the state of the art, we cannot regard the Kitselman patent as a pioneer patent, but think its claims must be limited in their scope to the actual combination of essential parts as shown ....”). 
Comiskey strongly suggested, if not required, that $\S 101$ be decided before everything else. ${ }^{128}$

That is a mistake. There were many, many ways to reject Bilski's claim 1. As a result, both the Federal Circuit and the Supreme Court approached the case with the preconception that Bilski should lose, and looked to the only available doctrine allowed by the procedural posture- $\S 101$ - to make sure that he did. ${ }^{129}$ And so neither court was too careful about the doctrine it created or how it applied that doctrine, because the result in that case was foreordained.

We think a subject-matter-first approach is backwards. Our claimoverbreadth approach requires careful attention to what the patentee invented, what came before, and what might come after. It can't logically be applied in advance of thinking about the other issues in a patent case. Indeed, we agree with a number of commentators that the right time to apply $\S 101$ is as a backstop after all other validity doctrines have been exhausted. ${ }^{130}$ We don't need the abstract ideas doctrine to weed out claims like Bilski's claim 1. Only once an invention is deemed new, nonobvious, described, and enabled should we ask whether there is nonetheless some reason to limit a claim. Asking the question later is likely both to produce a clearer answer - courts will have to think carefully about why they are rejecting such a claim—and to reduce the risk that we inappropriately carve entire areas of invention out of the patent system.

\section{Applying the Scope-Based Patentable Subject Matter Analysis}

We now apply our theory and factors to a variety of controversial claims. Of course, the evidence relating to these claims may differ from what we see in reported opinions; as such, reasonable minds can differ based on varying understandings of the factors involved.

We first address the PTO's request for examples of what might or might not constitute abstract ideas. While we believe that this Article might offer the PTO guidance, provision of specific examples would be fruitless. Indeed, that is the point of an overclaiming approach rather than a gatekeeper approach. We cannot know whether a particular claim is too abstract until we understand the inventive principles, prior art, industries, and potential downstream inventions. Of course, we can hypothesize, as we did with our example of the catheter inventor claiming "all noninvasive surgery," but such absurd claims are rare,

128. See In re Comiskey, 499 F.3d 1365, 1371 (Fed. Cir. 2007). But see In re Bilski, 545 F.3d at 950-51 n.1 (stating that Comiskey did not require patentable subject matter to be examined first).

129. Cf. Michael Risch, The Idea's the Thing, Legal Times, May 12, 2008, available at http://law.wvu.edu/r/download/9874 (expressing concern that the weakness of Bilski's application would cause courts to create over-restrictive subject matter rules).

130. See, e.g., Christopher T. Abernethy, Cruel Hand of Bilski: Culminating the Shortsighted Crusade for Marginalization of the 'Process' Patent 27-37 (May 2009) (unpublished comment), available at http://papers.ssrn.com/sol3/papers.cfm?abstract_id=1420205. 
and-like Bilski's-are almost always invalid for many reasons unrelated to their abstractness. We thus focus on some closer cases.

One such case is Metabolite, ${ }^{131}$ in which the patentee claimed a method for diagnosing a vitamin deficiency by measuring total homocysteine in the blood and correlating elevated levels with a deficiency. ${ }^{132}$ Three Justices argued that this claim was an unpatentable natural phenomenon. ${ }^{133}$ While some agree, others criticize this view because every medical diagnostic method (and most every treatment method) boils down to a natural phenomenon. ${ }^{134}$

Our analysis would instead focus on whether the claim is an application of the natural phenomena or whether it is so broad as to be unmoored from any specific application. It is difficult to dispute that the use of the relationship between total homocysteine and vitamin levels to diagnose a deficiency is applied in some sense, because it is implemented in a specific test that compares the relationship between two substances in the body. At the same time, the claim is broad, because any homocysteine test-including tests not yet invented-will infringe if it is used to diagnose the deficiency.

The question becomes whether the claim is overbroad in the $\S 101$ sense. Importantly, the claim does not preclude follow-on invention of new kinds of general diagnostic tests that measure the relationship between any and all substances in the body. Rather, the Metabolite test diagnoses a particular vitamin deficiency. Further, it uses one particular blood test-total homocysteines-not every blood test. Others are free to develop new blood measurements and new ways to test for this particular deficiency, even if they cannot use the particular method disclosed in the patent. And the claim does not cover other possible uses of the relationship, such as medical interventions that aim at reducing total homocysteine. Applying some of our factors, the technology was not generative and the industry is not particularly speedy, so the risk of locking up further improvements to this specific test seems low. Further, the claim appears to be tied to the disclosed embodiment because the inventors described the principles at work and the failures of other tests. In short, we find it unlikely that future inventors were blocked from creating new diagnostic tests in general, or even new ways to diagnose this particular deficiency. The primary concern, instead, was that downstream users would have to pay to exploit the discovery of the inventors, but that potential comes with every patent; there is no guarantee any downstream user will be able to invent around any particular patent claim.

131. Lab. Corp. of Am. Holdings v. Metabolite Labs., Inc., 126 S. Ct. 2921 (2006). Disclosure: Author Mark A. Lemley represented the patentee in this case.

132. See Metabolite Labs., Inc. v. Lab. Corp. of Am. Holdings, 370 F.3d 1354, 1358-59 (Fed. Cir. 2004), cert. dismissed, 126 S. Ct. 2921 (2006).

133. See Metabolite Labs., 126 S. Ct. at 2922, 2927 (Breyer, J., dissenting).

134. See Risch, supra note 61, at 600 ("Everything that happens may be deemed the work of nature .... .” (quoting Funk Bros. Seed Co. v. Kalo Inoculant Co., 333 U.S. 127, 134-35 (1948) (Frankfurter, J., concurring)) (internal quotation marks omitted)). 
Another medical diagnostic test example is Prometheus, ${ }^{135}$ in which the patentee claimed a method for adjusting medication for any given patient by measuring how much of the medicine's metabolites appear in that patient's body. ${ }^{136}$ The district court invalidated the patent because the amount of metabolization by any given patient was a natural phenomenon. ${ }^{137}$ The Federal Circuit reversed, holding (both before and again after Bilski) that because the drug was transformed in the human body — and indeed transformed the body itselfthe patent satisfied the machine-or-transformation test. ${ }^{138}$ Neither of these rulings is particularly helpful from an abstract ideas standpoint. The district court's focus was misplaced because there was nothing natural about the drug's effect on the body - it was an artificial drug and no human would ever react to it in nature. ${ }^{139}$

The Federal Circuit's analysis, by contrast, would allow too much. A patent claim can transform something and still be overbroad. If, for example, the patentee claimed all correlations of every drug in the body, the claim would certainly be abstract but would still pass the Federal Circuit's test. Our approach provides a way out of the thicket. Here, the claim was to very specific measurements of a particular drug. Like Metabolite, Prometheus involves an application of the natural principles discovered by the patentee. It is not generative, nor will it unduly bar future inventors. If, however, this claim were expanded to cover all drugs without any specific measurements, then it would be an abstract idea.

Metabolite and Prometheus concern inventions in the biotech and medical fields. Another field worthy of discussion is computer software. As we mentioned earlier, in Benson, the Supreme Court found a claimed algorithm used to convert data on a computer from one format to another was too broad, because it was not moored to any specific practical application. As such, it unduly prevented follow-on invention because it wholly preempted all use of the algorithm in any application whatsoever.

As we also noted, however, the Board of Patent Appeals \& Interferences has out-of-hand rejected software claims under the machine-or-transformation test that require a more rigorous analysis under our proposed test. For instance, in Ex parte Heuer, the Board rejected a claim to a method for decoding a binary

135. Mayo Collaborative Servs. v. Prometheus Labs., 130 S. Ct. 3543 (2010) (granting certiorari, vacating underlying judgment, and remanding for reconsideration in light of Bilski).

136. Prometheus Labs., Inc. v. Mayo Collaborative Servs., 581 F.3d 1336, 1340 (Fed. Cir. 2009), vacated and remanded, 130 S. Ct. 3543.

137. See Prometheus Labs. v. Mayo Collaborative Servs., No. 04cv1200, 2008 U.S. Dist. LEXIS 25062 (S.D. Cal. Mar. 28, 2008), rev'd, 581 F.3d 1336, vacated and remanded, 130 S. Ct. 3543.

138. See Prometheus, 581 F.3d at 1345-46; see also Prometheus Labs., Inc. v. Mayo Collaborative Servs., 628 F.3d 1347, 1349 (Fed. Cir. 2010) (on remand).

139. See Brief of Amici Curiae Interested Patent Law Professors in Support of Neither Party at 1, Prometheus, 581 F.3d 1336 (No. 2008-1403). 
representation of a document, finding that nothing in the specification required any "hardware" and therefore no machine was claimed under the machine-ortransformation test. ${ }^{140}$ Under an appropriate $\S 101$ scope analysis, the relevant concern is not whether there is a physical machine per se in the specification or claim language. Rather, the question should be whether the claim is so abstract and sweeping as to preclude all uses of the inventive idea, or whether it is sufficiently applied.

The proposed claim in Heuer is similar to that of Benson in that it concerns a method for converting a set of data from one format to another. Unlike the algorithm in Benson, however, the claim in Heuer does not cover a general algorithm, but instead a method of converting an XML-document that comprises particular steps. This factor weighs heavily in favor of patentability. On the other hand, those steps are relatively broad and cover implementations on any type of machine using any kind of XML data, including those not yet invented-indeed, the claim is not even limited to a general-purpose computer. Because the software industry is rapidly changing, under our proposed test one might argue that the claim should be moored to a specific type of computer or data structure to pass muster. Yet such an insistence would in essence require all software claims to be limited to those types of computers in use today. This kind of approach would unquestionably limit the value of software patents, and in a way that is unnecessary to adequately protect follow-on invention. Instead, a better way to cabin the broad scope of software patents is, in addition to determining whether the claim itself essentially covers merely the abstract idea at issue, to examine the contribution of the inventor relative to the prior art.

As we noted earlier, this examination is distinct from a $\S 112$ analysis. Although an inventor will often meet the written description and enablement standards by merely disclosing a few examples, for claims that could significantly impede follow-on invention (such as Heuer's) a more searching review may be advisable. Here, the question becomes whether Heuer disclosed sufficient embodiments to justify the relatively broad language in his proposed claim. In other words, does the disclosure justify the scope of preclusion of potential follow-on inventions embodying the general method claimed? This analysis will turn on the views of experts and others skilled in the relevant art, and thus, we cannot answer the $\S 101$ scope question at issue in Heuer here. Indeed, because this sort of analysis will not always be straightforward, we suggest that it be done last in any given case, after a review for novelty, nonobviousness, utility, and § 112 disclosure requirements.

Another difficult case under our test arises in the context of sports movessuch as patenting a new type of curveball. In some sense, a pitcher throwing a curveball might be argued to pass the machine-or-transformation test in the sense that the pitcher's body and the ball's location, velocity, and spin are

140. See Ex parte Heuer, No. 2009-004590, 2010 WL 3072973, at *8 (B.P.A.I. Aug. 4, 2010). 
transformed. ${ }^{141}$ The common intuition, however, is that this sort of claim should not be patentable subject matter, either because it does not concern technology or is too far afield from what is typically patentable. Apparently for this reason, the proposed PTO guidelines categorically classify "human behavior," particularly "exercising," as an example of a "general concept" that weighs against patent eligibility. Yet some human behavior-indeed, even some forms of exercise - should be eligible subject matter. Consider, for example, a novel method of exercising that helps relieve knee pain. Under the machine-or-transformation test, it is difficult to distinguish new exercise that is designed to cure a malady from one that merely increases the number of stristrikeouts.

However, under our proposed test-whether the claim is moored to specific, practical application - these distinctions are not as arbitrary. In particular, a novel exercise that helps cure knee pain would be a specific, practical application of the inventive ideas underlying the exercise. And this application would generally not foreclose other inventors from devising some new exercise to cure knee pain.

So too with a novel method of throwing a particular kind of curveball. A new motion that leads to a particular practical result with a baseball should probably be patentable. Arguably, patenting would not prevent follow-on invention if the claims were narrow. If, however, the claim were to every method of controlling ball motion using spin, then the claim would be more generative and likely too abstract. Pitching doesn't change rapidly. Nor is the claim not applied-this seems a very specific application of the general inventive principle. This is not to say that a new curveball is otherwise patentable-it may be obvious, it may not have operable utility, or it may not be definite. It is, however, allowable subject matter. ${ }^{142}$

\section{CONCLUSION}

The abstract ideas limitation on patentable subject matter has long been a puzzle, one Bilski did little to resolve. We think the dominant conception of $\S 101$ as a gatekeeper, excluding certain inventions from the patent system altogether, is wrong. We don't exclude inventions from patentability because the invention is too abstract. We refuse to patent certain claims when those claims reach too broadly and thereby threaten downstream innovation. Reconceiving abstract ideas as a scope limitation not only helps to explain the case law, but it

141. See Magliocca, supra note 52, at 876 n.7.

142. There may, of course, be "fairness" concerns in the game that counsel in favor of allowing pitchers to freely throw a new type of curveball, but such issues are best handled by league rules and not by courts determining what should be patentable. See Risch, supra note 61, at 645 . 
June 2011]

LIFE AFTER BILSKI

1347

avoids the disastrous consequences associated with the machine-ortransformation test. 


\section{LIFE AFTER BILSKI ${ }^{\dagger}$}

\section{Mark A. Lemley, ${ }^{*}$ Michael Risch, ${ }^{* *}$ Ted Sichelman*** \& R. Polk Wagner****}

In Bilski v. Kappos, the Supreme Court declined calls to categorically exclude business methods-or any technology - from the patent law. It also rejected as the sole test of subject matter eligibility the Federal Circuit's deeply-flawed machine-or-transformation test, under which no process is patentable unless it is tied to a particular machine or transforms an article to another state or thing. Subsequent developments threaten to undo that holding, however. Relying on the Court's description of the Federal Circuit test as a "useful and important clue," the U.S. Patent and Trademark Office, patent litigants, and district courts have all continued to rely on the machine-or-transformation test in the wake of Bilski: no longer as the sole rule, but as a presumptive starting point that threatens to effectively become mandatory. In this Article, we suggest a new way to understand the exclusion of abstract ideas from patentable subject matter. No class of invention is inherently too abstract for patenting. Rather, the rule against patenting abstract ideas is an effort to prevent inventors from claiming their ideas too broadly. By requiring that patent claims be limited to a specific set of practical applications of an idea, the abstract ideas doctrine both makes the scope of the resulting patent clearer and leaves room for subsequent inventors to improve upon-and patent new applications of -the same basic principle. Recasting the abstract ideas doctrine as an overclaiming test eliminates the constraints of the artificial machine-or-transformation test, as well as the pointless effort to fit inventions into permissible or impermissible categories. It also helps understand some otherwise-inexplicable distinctions in the case law. Testing for overclaiming allows courts to focus on what really matters: whether the scope of the patentee's claims are commensurate with the invention's practical, real-world contribution. This inquiry, we suggest, is the touchstone of the abstract ideas analysis, and the way out of the post-Bilski confusion.

$\dagger$ (C) 2011 The authors and the Trustees of Leland Stanford Jr. University.

* William H. Neukom Professor, Stanford Law School; Partner, Durie Tangri LLP.

** Associate Professor, Villanova University School of Law.

*** Assistant Professor, University of San Diego School of Law.

**** Professor of Law, University of Pennsylvania Law School.

Thanks to Rose Hagan and the participants at the Stanford Law Review symposium on Bilski for comments on a previous draft, and to Dustin Bednarz for research assistance. 
INTRODUCTION.

I. ThE RETURN OF MACHINE-OR-TRANSFORMATION.......................................1317

A. The History of Patenting Software ......................................................1317

B. The Persistence of the Machine-or-Transformation Test..........................1319

C. The Perils of the Machine-or-Transformation Test...................................1322

II. The Theory OF SubJEct MAtTER Restrictions............................................1325

A. Prior Subject Matter Theories .................................................................1326

B. Abstract Ideas as Scope Limitation .......................................................1328

C. Distinguishing the Scope Limitations in $\S 101$ and $\S 112$......................1329

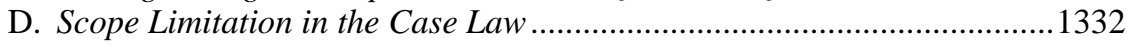

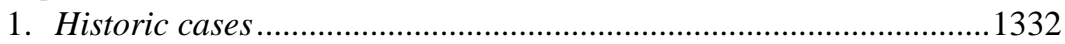

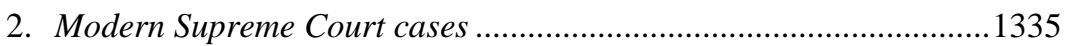

III. A PROPER APPROACH TO IDENTIFYING CLAIMS THAT IMPERMISSIBLY

COVER ABSTRACT IDEAS......................................................................1337

A. The Failure of the Machine-or-Transformation Test .............................1338

B. Identifying Abstract Ideas .................................................................1339

C. Overclaiming and the Decision Process ...................................................1341

D. Applying the Scope-Based Patentable Subject Matter Analysis ................1342

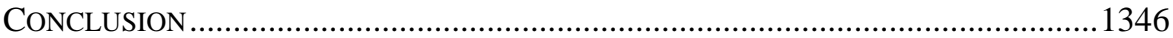

\section{INTRODUCTION}

In Bilski v. Kappos, the Supreme Court rejected calls to categorically exclude business methods - or any technology — from the scope of patent law. ${ }^{1}$ It also rejected as the sole test of subject matter eligibility the Federal Circuit's deeply-flawed machine-or-transformation test, under which no process, and perhaps no invention of any type, is patentable unless it is tied to a particular machine or transforms an article to another state or thing. ${ }^{2}$ Nonetheless, the Court held that the machine-or-transformation test still "is a useful and important clue, an investigative tool, for determining whether some claimed inventions" are patentable subject matter. ${ }^{3}$ The result was a (narrow) victory for inventors, as well as for context-specific standards over formal rules.

Subsequent developments threaten to undo that win, however. Relying on the Court's "useful and important clue" language, the U.S. Patent and Trademark Office (PTO), patent litigants, and district courts have all continued to rely on the machine-or-transformation test in the wake of Bilski: no longer as the sole rule, but as a presumptive starting point that threatens to become effectively mandatory. Put simply, the problem is that no one understands what makes an idea "abstract,"4 and hence ineligible for patent protection, so decisionmakers fall back on the one test that has been articulated.

1. 130 S. Ct. 3218 (2010).

2. See In re Bilski, 545 F.3d 943, 954 (Fed. Cir. 2008) (en banc).

3. $130 \mathrm{~S}$. Ct. at 3227.

4. See Interim Guidance for Determining Subject Matter Eligibility for Process Claims in View of Bilski v. Kappos, 75 Fed. Reg. 43,922 (July 27, 2010) (providing an ex- 
In this Article, we suggest a new way to understand the exclusion of abstract ideas from patentable subject matter. No class of invention is inherently too abstract for patenting. Rather, the rule against patenting abstract ideas is best understood as an effort to prevent inventors from claiming their ideas too broadly. By requiring that patent claims be limited to a specific set of practical applications of an idea, the abstract ideas doctrine both makes the scope of the resulting patent clearer and leaves room for subsequent inventors to improve upon - and patent new applications of - the same basic principle.

Understanding the abstract ideas doctrine as an overclaiming test eliminates the constraints of the artificial machine-or-transformation rule, as well as the pointless effort to fit inventions into permissible and impermissible categories. It also helps understand some otherwise-inexplicable distinctions in the case law. A focus on overclaiming allows courts to focus on what really matters: whether the scope of the patentee's claims is commensurate with the invention's practical, real-world contribution, rather than asserting coverage over general ideas unmoored to a specific application. This inquiry, we suggest, is the touchstone of the abstract ideas analysis, and the way out of the post-Bilski confusion.

In Part I, we discuss the rise, fall, and apparent rebirth of the Federal Circuit's machine-or-transformation test, and explain why it is so problematic. In Part II, we offer a new way of thinking about abstract ideas, one focused on the scope of the patentee's claims rather than the category of the invention. In Part III, we apply our test to a variety of current cases and problems.

\section{THE RETURN OF MACHINE-OR-TRANSFORMATION}

\section{A. The History of Patenting Software}

The patentability of software and business methods has a long and tortured history. Put extremely briefly: The Supreme Court in the 1970s struggled with mathematical algorithm and software patents, first refusing to patent a mathematical algorithm, ${ }^{5}$ but later holding that a process could be patented even though its novel elements included software so long as that software was tied to a particular machine. ${ }^{6}$ After these cases, the Supreme Court got out of the business of patentable subject matter for nearly thirty years. ${ }^{7}$

planation of considerations to use in determining subject matter eligibility of method claims in view of the abstract idea exception).

5. See Parker v. Flook, 437 U.S. 584, 594-95 (1978); Gottschalk v. Benson, 409 U.S. 63, 65, 71-72 (1972).

6. See Diamond v. Diehr, 450 U.S. 175, 187, 191-93 (1981) ("On the other hand, when a claim containing a mathematical formula implements or applies that formula in a structure or process which, when considered as a whole, is performing a function which the patent laws were designed to protect (e.g., transforming or reducing an article to a different state or thing), then the claim satisfies the requirements of $\S 101 \ldots$. [W] do not view res- 
Through the 1980s and 1990s, courts gradually eroded the requirement that a software invention be tied to a particular machine. ${ }^{8}$ Finally, in 1998, in State Street, the Federal Circuit eliminated any such requirement, holding that both software alone and business methods were patentable regardless of the form in which they were implemented, if the invention produced a "useful, concrete, and tangible result," even one expressed in numbers. ${ }^{9}$

For a decade after 1998, patentable subject matter was effectively a dead letter. That changed dramatically in 2008 when the Federal Circuit decided In re Bilski en banc. The case involved a patent application on a method of hedging risk in the sale of commodities. The patent application also included dependent claims that limit the method to use in the energy industry and one dependent claim that offers a formula for calculating risk-adjusted prices. The FederFederal Circuit ruled, eleven to one, that Bilski's claimed method of hedging financial risk was unpatentable. ${ }^{10}$

The Federal Circuit crafted what has come to be known as the machine-ortransformation test: “A claimed process is . . p patent-eligible under $\S 101$ if: (1) it is tied to a particular machine or apparatus, or (2) it transforms a particular article into a different state or thing."11

Moreover, even if a process meets this test, it is unpatentable if the machine or transformation is merely incidental extra-solution activity. ${ }^{12}$ And an invention that preempts all use of a law of nature or algorithm, even in a particular field of use, is not patentable even if it would otherwise survive the test. Purporting to derive this test from Supreme Court precedent, the Federal Circuit displaced all prior tests for patentable subject matter, including State Street's "useful, concrete, and tangible result" analysis. ${ }^{13}$

The Supreme Court granted certiorari and affirmed that Bilski's invention was unpatentable as an abstract idea. ${ }^{14}$ However, the Court rejected the machine-or-transformation analysis as the exclusive test of patentability, ${ }^{15}$ though

pondents' claims as an attempt to patent a mathematical formula, but rather to be drawn to an industrial process for the molding of rubber products ....”).

7. The one exception-J.E.M. Ag Supply, Inc. v. Pioneer Hi-Bred Int'l, Inc., 534 U.S. 124 (2001) — involved the interaction of the patent statute with other specialized statutes protecting plants.

8. For a discussion of this history, see Julie E. Cohen \& Mark A. Lemley, Patent Scope and Innovation in the Software Industry, 89 CALIF. L. REV. 1 (2001).

9. State St. Bank \& Trust Co. v. Signature Fin. Grp., 149 F.3d 1368, 1373 (Fed. Cir. 1998) (internal quotation marks omitted).

10. In re Bilski, 545 F.3d 943 (Fed. Cir. 2008) (en banc). While there were three dissents, only Judge Pauline Newman would have found the claims to be patentable subject matter.

11. Id. at 954 .

12. See id. at 957.

13. Id. at 959-61.

14. See Bilski v. Kappos, 130 S. Ct. 3218, 3229-30 (2010).

15. See id. at 3227. 
all the Justices thought that the test was an "important clue" to patentability. ${ }^{16}$ Alas, the Court's majority did not provide additional guidance on why Bilski's invention was unpatentable. ${ }^{17}$

\section{B. The Persistence of the Machine-or-Transformation Test}

Patent owners narrowly dodged a bullet in Bilski. No one except perhaps Bilski himself thought that he would get a patent. ${ }^{18}$ However, four Justices would have held business methods unpatentable altogether, ${ }^{19}$ and in the course of doing so would have substantially limited patentable subject matter. Thus, the fact that Justice Kennedy's opinion for the Court rejected strict application of the machine-or-transformation test and left open the prospect of patenting software and business methods led early commentators to declare it a victory for patent owners in those industries. ${ }^{20}$

In fact, the PTO and the few district courts to have decided cases since Bilski have continued to apply the machine-or-transformation test. For example, in Ultramercial, $L L C$ v. Hulu, $L L C$, the claims related to the process of displaying copyrighted media in exchange for watching certain advertising. ${ }^{21}$ The district court held that "even though the machine or transformation is no longer the litmus test for patentability, the Court will use it here as a key indicator of patentability."22

The PTO Board of Patent Appeals and Interferences (BPAI) has similarly focused on the machine-or-transformation test in analyzing post-Bilski claims. ${ }^{23}$ In Ex parte Tse-Huong Choo, the BPAI rejected a claim that it found "can exist solely in software and data structures."24 More importantly, the

16. Id. at 3227; id. at 3235 (Stevens, J., concurring in the judgment); id. at 3258 (Breyer, J., concurring in the judgment).

17. See, e.g., Kristen Osenga, Waiting for Bilski: A Patent Story 5 (July 12, 2010) (unpublished manuscript), available at http://papers.ssrn.com/sol3/papers.cfm?abstract_id $=1650061$ ("In the end, [Bilski] tells Bar and Academy nothing more than has already been said. The men remain in the same fog of confusion.”).

18. In fact, the Bilski patent had a co-inventor, Rand Warsaw. See Bilski, 130 S. Ct. at 3218. However, for simplicity, we assume in the text that Bilski was the sole inventor.

19. See id. at 3249 (Stevens, J., concurring in the judgment). Indeed, many believe that the concurrence was originally to be the majority opinion.

20. See, e.g., Peter S. Menell, Forty Years of Wondering in the Wilderness and No Closer to the Promised Land: Bilski's Superficial Textualism and the Missed Opportunity to Return Patent Law to Its Technology Mooring, 63 STAN. L. REV. 1289 (2011).

21. See No. CV 09-06918 RGK (PLAx), 2010 WL 3360098, at *1 (C.D. Cal. Aug. 13, 2010).

22. $I d$. at $* 3$.

23. For a full discussion of all board opinions since Bilski, see Dave Healey, BPAI: Tough on Software Claims Post-Bilski, РАT. МATH (Dec. 7, 2010), http://patentmath.com/ bpai-tough-on-software-claims-post-bilski.

24. No. 2009-006352, 2010 WL 2985362, at *2 (B.P.A.I. July 28, 2010). 
Board looked at a Beauregard claim ${ }^{25}$ and found that "merely reciting data or instructions on a stored computer readable medium does not make a claim statutory [subject matter] under $\S 101$. Similarly, merely placing instructions or code on a computer readable medium does not render claim 24 statutory.,26 Thus, the Board concluded that Bilski bars not just process but also article-ofmanufacture claims to software standing alone. ${ }^{27}$

The Board has been equally strict in applying the transformation step of the machine-or-transformation test to software. In Ex parte Heuer, the Board rejected a claim to a method for decoding a binary representation of a document. $^{28}$ The BPAI found that the claims failed both prongs of the machine-ortransformation test. It specifically looked at an "XML-based document," "a simplified schema," "a schema," "correction code," and "at least one decoder" and found that nothing in the specification indicating that they "must be hardware" and that there was therefore no machine. ${ }^{29}$ On the transformation side, the BPAI found that " $[\mathrm{t}] \mathrm{he}$ fact that Appellants' XML-based document is decoded using the claimed 'namespace' or the claimed 'simplified schema' fails to qualify as a transformation of an article of manufacture consistent with the second prong of the 'machine-or-transformation' test." ${ }^{30}$ The latter ruling seems to be more restrictive than the Federal Circuit decision in In re Bilski, since it doesn't permit transformation of anything other than an article of manufacture, while the Federal Circuit had appeared willing in Bilski to allow some transformations of data to meet the machine-or-transformation test. ${ }^{31}$

The PTO issued guidance in interpreting Bilski in July 2010, identifying various factors that could affect patentable subject matter eligibility; all of

25. Beauregard claims are directed to software stored on a medium such as a CDROM claimed as an article of manufacture. See In re Beauregard, 53 F.3d 1583, 1584 (Fed. Cir. 1995).

26. Tse-Huong Choo, 2010 WL 2985362, at *5 (citations omitted); accord Ex parte Kelkar, No. 2009-004635, 2010 WL 3768175 (B.P.A.I. Sept. 24, 2010).

27. See also Ex parte Christian, No. 2009-006589, 2010 WL 3389297, at *2 (B.P.A.I. Aug. 23, 2010) ("A claim that recites no more than software, logic, or a data structure (i.e. an abstraction) does not fall within any statutory category. . . . 'Abstract software code is an idea without physical embodiment.'” (citation omitted) (quoting Microsoft Corp. v. AT\&T Corp., 550 U.S. 437, 449 (2007))); Ex parte Ramanujam, No. 2009-002483, 2010 WL 3214559 , at *4 (B.P.A.I. Aug. 12, 2010) (finding that claims "are therefore directed to software per se, which falls outside the scope of patentable subject matter”); Ex parte Caccavale, No. 2009-006026, 2010 WL 2901727, at *5 (B.P.A.I. July 23, 2010) (“Claim 8 simply fails to recite that the computations are performed by the 'distributed processing units' or any other machine in claim 8.”). Contra Ex parte Russo, No. 2009-001876, 2010 WL 3441058 (B.P.A.I. Aug. 30, 2010) (holding a system claim directed to data structures unpatentable, but a Beauregard claim to the same data structures patentable).

28. No. 2009-004590, 2010 WL 3072973 (B.P.A.I. Aug. 4, 2010); accord Ex parte Venkata, No. 2009-007302 (B.P.A.I. Oct. 5, 2010); Ex parte MacKenzie, No. 2009-007332 (B.P.A.I. Oct. 4, 2010).

29. Heuer, 2010 WL 3072973 , at *8.

30. Id.

31. See In re Bilski, 545 F.3d 943, 961-63 (Fed. Cir. 2008) (en banc). 
those factors relate generally to the machine-or-transformation test or are implementations of it. ${ }^{32}$ We have heard reports that patent examiners are more lenient than the Board generally has been, allowing claims to general-purpose computers programmed with software and rejecting only pure software claims. ${ }^{33}$ But by the nature of the appellate process, it is the Board decisions that are likely to shape the law in future cases.

In December 2010, the Federal Circuit decided Research Corp. Technologies v. Microsoft Corp., holding that software method claims directed to a process of "halftoning" printed images were not unpatentable abstract ideas because the invention "presents functional and palpable applications in the field of computer technology." 34 The opinion noted that other (unasserted) claims in the patent required the use of specific machines, demanded evidence that the claim be "manifestly abstract" before holding it invalid, and went so far as to suggest that "inventions with specific applications or improvements to technologies in the marketplace are not likely to be so abstract” as to fail § $101 .^{35}$ The court did not apply the machine-or-transformation test, and indeed suggested (wrongly) that the Supreme Court had rejected that test as nonstatutory. ${ }^{36}$ The court suggested that $\S 112$ may better serve the goal of limiting overbroad claim language. ${ }^{37}$

Research Corp. is an encouraging sign that the machine-or-transformation test may not dominate the post-Bilski landscape. Indeed, it might suggest a return to the State Street form of analysis. But some caution is warranted. The case was written by Judge Rader, and joined by Judge Newman, the two judges who dissented from the machine-or-transformation test in In re Bilski. It contains some specious reasoning that is hard to square with prior court precedent, such as its conclusion that structural limitations in dependent claims render patentable different, independent claims that lack those limitations. ${ }^{38}$ And it does

32. See Interim Guidance for Determining Subject-Matter Eligibility for Process Claims in View of Bilski v. Kappos, 75 Fed. Reg. 43,922 (July 27, 2010).

33. One Board opinion supports this more lenient approach. See Ex parte Ulf, No. 2009-008071, 2010 WL 3611779, at *8 (B.P.A.I. Sept. 7, 2010) (“Dependent claim 4 explicitly recites 'an inquiry, made on an opportunity reservation computer database.' In particular, since a computer is required to query a computer database, we find evidence that the method steps of dependent claim 4 are implemented on a 'machine.' Therefore, claim 4 is tied to a 'machine' consistent with the bounds of the machine-or-transformation test."). But see Ex parte Aklilu, No. 2009-007075, 2010 WL 4315178, at *4 (B.P.A.I. Oct. 29, 2010) ("[M]ere use of a generic machine or a general purpose computer to perform the steps of an otherwise unpatentable algorithm is not sufficient to meet the requirements for $\S 101$ statutory subject matter.”).

34. 627 F.3d 859, 868 (Fed. Cir. 2010).

35. Id. at 869 .

36. See id. at 868 .

37. See id. at 869.

38. See id. ("The fact that some claims in the '310 and '228 patents require a 'high contrast film,' 'a film printer,' 'a memory,' and 'printer and display devices' also confirm [sic] this court's holding that the invention is not abstract.”). 
not offer a detailed test of its own, instead simply holding that the claims at issue are not abstract (albeit with some discussion). Given that the Federal Circuit created the machine-or-transformation test, it seems quite possible that the majority of the court will incline to the views of the BPAI and the district courts that the machine-or-transformation test continues to govern in most instances, distinguishing Research Corp. on its facts.

Indeed, some reason to think that likely came just over a week later, in Prometheus Laboratories, Inc. v. Mayo Collaborative Services. ${ }^{39}$ The court there reaffirmed the patentability of a method for optimizing drug dosages during therapy. But in doing so, the Federal Circuit held that the Supreme Court "did not disavow the machine-or-transformation test" and had instead indicated "that " $\mathrm{t}$ ]ransformation and reduction of an article to a different state or thing is the clue to the patentability of a process claim that does not include particular machines." " ${ }^{40}$ The contradictory statements of the Federal Circuit in Research Corp. and Prometheus suggest that the role of the machine-or-transformation test will be at least subject to ongoing debate.

\section{The Perils of the Machine-or-Transformation Test}

The machine-or-transformation test is problematic. It contains a number of ambiguities, leads to some bizarre results, and poorly tracks the stated goal of preventing the patenting of abstract ideas.

First the ambiguities. Does the machine-or-transformation test apply only to process claims? The prior Supreme Court cases in Benson, Flook, and Diehr were all process claims. ${ }^{41}$ The Federal Circuit decision in In re Bilski distinguishes In re Nuijten as directed to an article of manufacture, not a process, ${ }^{42}$ but does not do the same for In re Alappat, an en banc decision holding that a new computer program automatically makes a general-purpose computer "a new machine." 43 The BPAI and the district courts have generally held that the machine-or-transformation test is not limited to process claims. And there is no logical reason to cabin the holding to process claims; Benson and Diehr were process claims, but the Court's analysis did not focus on that fact. If the machine-or-transformation test were limited to process claims, it would generally

39. 628 F.3d 1347 (Fed. Cir. 2010).

40. Id. at 1355 (alteration in original) (emphasis added) (quoting Bilski v. Kappos, 130 S. Ct. 3218, 3227 (2010)) (some internal quotation marks omitted).

41. See infra Part II.D.2.

42. See In re Bilski, 545 F.3d 943, 951 n.2 (Fed. Cir. 2008) (en banc). The court dodged the question about whether Nuijten's process for creating signals sufficed.

43. In re Alappat, 33 F.3d 1526, 1545 (Fed. Cir. 1994) (en banc); see In re Bilski, 545 F.3d at 958-60. 
be easy to draft around; most computer-implemented process claims can be rewritten as a machine or article of manufacture claims. ${ }^{44}$

Second, is a general-purpose computer a "specific machine," as per Alappat? The Federal Circuit expressly reserved this question in In re Bilski. ${ }^{45}$ If it is, Bilski arguably invalidates tens of thousands of existing patents but will be easy to draft around in the future. But it would be a bit odd to say that Bilski's hedging method becomes patentable if he adds "in a computer" at the end. The BPAI has mostly (and the district courts have unanimously) read Bilski to say that a general-purpose computer is not enough, though patent examiners have reportedly been more forgiving of such claims. ${ }^{46}$

If these ambiguities are resolved — as they seem to have been so far-by concluding that you cannot evade the machine-or-transformation test by adding the phrase "in a computer" or by redrafting the claim as a system claim, the machine element of the machine-or-transformation test appears to be quite restrictive. That in turn leads to some bizarre results. It will lead to efforts to draft claims to software run on specific machines, but-since the computer used is irrelevant in most software patents-patentees may try to write dozens of claims, each to a specific "machine” implementing their program. If that works, owners of existing patents will find their claims invalid because they didn't use the "magic words," 47 but going forward the strategy may allow patentees to approximate the effect of claiming their software on a general-purpose computer. If it doesn't work, the law will be drawing artificial distinctions between programs of equivalent inventiveness. For example, it seems pointless to say that the same software invention is patentable if it works only in an MRI machine but unpatentable if otherwise-identical software can be run on a PC.

At the same time, application of that rule seems underinclusive. Suppose we write a new song. ${ }^{48}$ Can we patent it? Not as such, but arguably the song could pass the machine-or-transformation test if we record it using an iTunes codec and claim it as a method implemented digitally on an MP3 player. After all, the song is claimed only on particular machines specially designed for that purpose. ${ }^{49}$ How about the arbitration process in Comiskey ${ }^{50}$ Does it really be-

44. A process that is implemented in a computer can be claimed either as a process or as a computer system that is programmed to perform the steps of the process. Only the form has changed.

45. See 545 F.3d at 962 ("We leave to future cases the elaboration of the precise contours of machine implementation, as well as the answers to particular questions, such as whether or when recitation of a computer suffices to tie a process claim to a particular machine.”).

46. See supra note 33 and accompanying text.

47. Cohen \& Lemley, supra note 8, at 9 (describing the "doctrine of the magic words").

48. Don't worry, we haven't.

49. Cf. In re Alappat, 33 F.3d 1526, 1554 (Fed. Cir. 1994) (Archer, C.J., concurring in part and dissenting in part) ("Through the expedient of putting his music on known structure, can a composer now claim as his invention the structure of a compact disc or player piano 
come patentable if run on a particular computer? We are confident that the adopters of the machine-or-transformation test didn't intend those results. A specific machine seems an unnecessary limitation in some cases, and an insufficient one in others. The reason is the same in both cases: the test is focusing on the tail (the prior art machine with which the new invention works) and ignoring the dog (the new invention itself).

Application of the transformation prong of the machine-or-transformation test produces even more bizarre results. What does it mean to transform something "to another state or thing"? The Federal Circuit in In re Bilski expressly rejected the idea from Comiskey that physical steps are required. ${ }^{51}$ But it also seemed to reimport that limitation by talking about machines or transformations of articles. The result is ambiguity whether a physical thing, or merely a relationship among things, needs to be transformed. Is FedEx patentable subject matter because packages are moved from place to place, or must the packages themselves be changed? Is a method of swinging a golf putter transformative because it results in a golf ball being moved to a different place than it otherwise would have been $?^{52}$

The Federal Circuit decision in In re Bilski suggests-mostly-that transformation requires some physical change to the patented thing itself. The Supreme Court language from which it is taken, after all, speaks of "[t]ransformation and reduction of an article to a different state or thing." Carving wood into a chair "transforms" it into a new thing-a chair. Chemical reactions change the state of the chemicals involved. But there remains the problem of whether the transformation is sufficient, especially with respect to process claims.

Unfortunately, the analysis becomes even more confusing. Despite the preference for physical transformation, the Federal Circuit in In re Bilski (in its oddest passage) concludes that transforming data itself can meet this test in certain circumstances. Citing Abele, the court distinguishes between invalid general claims to outputting data results and valid specific claims to outputting particular data made using a particular machine. ${ }^{54}$ The court endorses the latter as long as the data "represents physical objects or substances." 55 The machine is the same, the transformation is the same-a computer has different bits set than it otherwise would, which means that the electrical impulses across gates on its

roll containing the melody he discovered and obtain a patent therefor? The answer must be no.”).

50. See In re Comiskey, 499 F.3d 1365, 1368 (Fed. Cir. 2007).

51. See In re Bilski, 545 F.3d 943, 960-61 (Fed. Cir. 2008) (en banc).

52. Cf. Gerard N. Magliocca, Patenting the Curve Ball: Business Methods and Industry Norms, 2009 BYU L. REV. 875, 876 (describing the throwing of a curve ball as transformative).

53. Gottschalk v. Benson, 409 U.S. 63, 70 (1972) (internal quotation marks omitted).

54. See In re Bilski, 545 F.3d at 963.

55. Id. 
chips are in a different array. But to the Federal Circuit the result is transformative if, but only if, the data these bits refer to represents a physical thing. Kevin Collins has referred to this as meta-tangibility: the question is not whether the invention is tangible, but whether the intangible invention refers to something that is itself tangible. ${ }^{56}$

Coal (the subject of the contracts in Bilski) is plainly a real-world physical thing. Would claim 1 in Bilski survive if it added a reference to the physical thing that was the subject of the contract? If an algorithm can only be used in a computer (as in Benson), does displaying the results from that algorithm render the invention patentable? This approach makes no sense. As with the machine prong, the transformation test is not focused on the invention, but on something external to it.

The Federal Circuit created this meta-tangibility data transformation exception to explain the result in In re Abele. ${ }^{57}$ That case held that a narrow claim directed to a program that displayed the results of a CAT scan was patentable subject matter, but that a broad claim that purported to patent the use of a calculation to shade display images was not. ${ }^{58}$ But as described in In re Bilski, the distinction is illogical.

To presage our argument in Part II, the real issue in Abele is not whether the information being displayed relates to something physical. The issue is overclaiming. Tailored claims should survive even if they aren't transforming anything physical, but broad claims that encompass any sort of data shouldn't. But that's not the way it works under the machine-or-transformation test. If we hope to limit patentable subject matter in a predictable and rational way, the machine-or-transformation test is not the way to do it. In the next Part, we introduce our alternative.

\section{The TheORY OF SubJeCt MATter Restrictions}

Patent eligibility requires that the subject matter clear two primary hurdles. First, each claim must fall within one of the statutory buckets: process, machine, manufacture, or composition of matter. ${ }^{59}$ These groupings are categorical-either a claim falls within the statute or it does not.

Second, each claim must fall outside of one of the common law exceptions: abstract ideas, laws of nature, and natural phenomena. ${ }^{60}$ It is here that Bilski and its predecessors are the most opaque: each case purports to grant or deny

56. See Kevin Emerson Collins, An Initial Comment on In re Bilski: Tangibility Gone Meta, PATENTLY-O BLOG, 1 (Nov. 1, 2008), http://www.patentlyo.com/patent/law/ collinsmetabilski.pdf.

57. See In re Bilski, 545 F.3d at 962-63.

58. See In re Abele, 684 F.2d 902, 908 (C.C.P.A. 1982).

59. See 35 U.S.C. § 101 (2006).

60. See Bilski v. Kappos, 130 S. Ct. 3218, 3225 (2010). 
eligibility to a particular patent claim, but fails to provide guidance about how to handle the next claim. ${ }^{61}$ Bilski makes clear that while the Supreme Court has no intention of abandoning these old exceptions, neither does it intend to provide further guidance. Perhaps even worse, the guidance we have from the machine-or-transformation test isn't helping. A principled theory is needed.

\section{A. Prior Subject Matter Theories}

The traditional way academics think about patentable subject matter is as a gatekeeper: a means of excluding certain types of inventions entirely from the scope of patent protection. ${ }^{62}$ Gatekeeping approaches have proven unsatisfactory. While they may serve to reduce administrative and judicial costs in determining eligible subject matter, gatekeeping theories are necessarily bright-line rules: they will both exclude some patents that should be granted and fail to exclude others that should not. We think this unwise. The core mission of patent law is to create incentives for the production, disclosure, and commercialization of socially valuable inventions. The flexibility of any subject matter requirement is paramount given the rapidly changing nature of technology. For example, prior to Bilski, the Court last considered the scope of patentable subject matter in 1981, based on inventions made nearly a decade earlier. ${ }^{63}$ At the time those inventions were made, the biotechnology and personal computer industries were just starting, there was no such thing as a cell phone, and the Internet was something used by only a few computer scientists at universities. Had the Court created an inflexible rule in 1981 governing the patentability of software or communications technologies from 1970, that rule could have had a range of

61. See generally Michael Risch, Everything Is Patentable, 75 TEnN. L. Rev. 591, 649 (2008) (noting that current subject matter rules "cannot be applied narrowly").

62. See, e.g., Kevin Emerson Collins, Claims to Information Qua Information and a Structural Theory of Section 101, 4 I/S: J.L. \& POL’y FOR INFO. SOC’y 11 (2008); Kevin Emerson Collins, Propertizing Thought, 60 SMU L. REV. 317 (2007); Kevin Emerson Collins, Semiotics 101: Taking the Printed Matter Doctrine Seriously, 85 IND. L.J. 1378 (2010); Jay Dratler, Jr., Does Lord Darcy Yet Live? The Case Against Software and BusinessMethod Patents, 43 Santa Clara L. Rev. 823 (2003); Robert A. Kreiss, Patent Protection for Computer Programs and Mathematical Algorithms: The Constitutional Limitations on Patentable Subject Matter, 29 N.M. L. REV. 31, 86-87 (1999); Menell, supra note 20, at 1312-13 (arguing that patents should be limited to the technological arts); David S. Olson, Taking the Utilitarian Basis for Patent Law Seriously: The Case for Restricting Patentable Subject Matter, 82 Temp. L. Rev. 181, 184 (2009); Pamela Samuelson, Benson Revisited: The Case Against Patent Protection for Algorithms and Other Computer Program-Related Inventions, 39 EMORY L.J. 1025, 1042-43 (1990); Pamela Samuelson \& Jason Schultz, "Clues" for Determining Whether Business and Service Innovations Are Unpatentable Abstract Ideas, 15 LEWIS \& CLARK L. REV. 110 (2010) (arguing that business methods should generally be unpatentable despite Bilski); John R. Thomas, The Patenting of the Liberal Professions, 40 B.C. L. REv. 1139 (1999); Joshua D. Sarnoff, Patent Eligible Inventions After Bilski: History and Theory (Feb. 07, 2011) (unpublished manuscript), available at http://papers.ssrn.com/sol3/papers.cfm?abstract_id=1757272.

63. See Diamond v. Diehr, 450 U.S. 175 (1981). 
unintended consequences, preventing the patenting of important new inventions in a wide range of fields. Quite simply, innovation in industry must necessarily include innovation in applied processes.

Furthermore, gatekeeping rules don't have very clear lines; ${ }^{64}$ subject matter category delineation is notoriously elusive. There is no clear division between "software" and "nonsoftware" patents, or a computer system that implements a "business method" and one that implements another type of process, or between "technological" and "nontechnological" inventions. Lack of rigidity is not inherently bad; we suggest a flexible, factors-based test ourselves. But because gatekeeping rules attempt to draw conceptual lines around classes of technology with unclear boundaries-instead of using the policy-based factors that should drive patentable subject matter determinations - the result is a set of tests that overexclude and underexclude in a costly and haphazard way.

One of us has gone so far as to argue that the best solution is to abandon all exceptions, including the historical ones. ${ }^{65}$ Whether or not this approach is correct, it is unlikely to gain judicial support in light of Bilski. Therefore, we take the common law abstract ideas exception as a given, and seek to articulate a reason to preclude patentability for abstract ideas and a corresponding way to recognize when patent claims are too abstract. We recognize that this better way has been elusive. Even those commentators who agree that the abstract ideas exception is a scope limitation device fail to provide a principled way to apply the standard. ${ }^{66}$ Instead, they usually rely on $\S 112$ of the Patent Act, conflating overbreadth for patentable subject matter purposes with enablement and written description. ${ }^{67}$

64. Even the categories in the Patent Act are sometimes difficult to apply. See, e.g., Am. Fruit Growers, Inc. v. Brogdex Co., 283 U.S. 1, 10-13 (1931) (determining whether an orange dipped in borax is a "manufacture"); In re Nuijten, 500 F.3d 1346, 1353-57 (Fed. Cir. 2007) (determining whether an electrical signal falls into a statutory category).

65. See Risch, supra note 61, at 591.

66. For example, T.J. Chiang argues that patentable subject matter encompasses both gatekeeping and scope limitations, and suggests that the abstract ideas exclusion is primarily a scope limitation. Tun-Jen Chiang, The Rules and Standards of Patentable Subject Matter, 2010 Wis. L. REV. 1353, 1363, 1381. He does not, however, attempt to articulate the scopelimitation analysis. For other scope-related theories of patentable subject matter, see, for example, Efthimios Parasidis, A Uniform Framework for Patent Eligibility, 85 TuL. L. ReV. 323, 387-89 (2010); Jur Strobos, Stalking the Elusive Patentable Software: Are There Still Diehr or Was It Just a Flook?, 6 HARV. J.L. \& TECH. 363, 365 n.8 (1993); Bryan Treglia, Separating Abstract Ideas and Laws of Nature from Patentable Subject Matter, 48 JURIMETRICS J. 427, 434-37 (2008).

67. See, e.g., Donald S. Chisum, Weeds and Seeds in the Supreme Court's Business Method Patents Decision: New Directions for Regulating Patent Scope 8-10 (Oct. 27, 2010) (unpublished manuscript), available at http://ssrn.com/abstract=1698633. 


\section{B. Abstract Ideas as Scope Limitation}

We start with the unremarkable observation that the statutory categories outlined in $\S 101$ - process, machine, manufacture, and composition of matter"-are of relatively limited usefulness in analyzing whether a patent claim falls within patentable subject matter. Indeed, because patent claims almost never fall outside of the four fundamental categories of $\S 101$, when they do it is noteworthy. For example, in In re Nuijten, the Federal Circuit held that an electrical signal alone - not tied to any storage or transmission medium-did not fall within any of the categories. ${ }^{68}$ We might also think of the per se bars against claims that encompass laws of nature and no more, like gravity and relativity, as similar in kind: such claims are not patentable subject matter because, without more, they are usually not processes, machines, manufactures, or compositions of matter. By contrast, there is no per se bar to patenting laws of nature as applied in a process, machine, manufacture, or composition of matter. As a general matter, the traditional examples of barred subject matter are typically the easy cases. The harder (and more pressing) question is how to analyze claims falling within the statutory categories.

This is the role for the common law exceptions to patentable subject matter: excluding, for policy reasons, claims to subject matter irrespective of their categorical status. And in order to appropriately apply the exceptions, one must first understand their theory and the particular policy problem they are addressing.

In our view, the abstract ideas exception is directed to an inherent tension between two major policy goals of the patent system. First, inventors should be entitled to claim all that they have actually invented (or at least all that they have taught to the world via their patent disclosure) - thereby implementing the incentive structure that lies at the heart of the patent grant. Limiting inventors to the particular machine they developed would make patents a "hollow and useless thing." 69 Second, we want to further the progress of society by continually growing the storehouse of knowledge. In some cases, these goals can be in substantial tension-particularly where a patentee's claimed invention would curtail access to ideas that are in essence reserved to society.

But what ideas are reserved to society? Those that are fundamental, the building blocks of human thought: "A principle, in the abstract, is a fundamental truth; an original cause; a motive; these cannot be patented, as no one can claim in either of them an exclusive right.. ${ }^{, 70}$ Importantly, patentees can and

68. 500 F.3d at 1351, 1353. Even that conclusion was questionable as a matter of physics and statutory interpretation. John F. Duffy, In re Nuijten: Patentable Subject Matter, Textualism and the Supreme Court, PAtently-O Blog (Feb. 5, 2007), http://www.patentlyo.com/patent/DuffyOnNuijten.pdf. Even so, the policy consequences of holding that a signal is "made" whenever it passes through a wire would have been dire.

69. Graver Tank \& Mfg. Co. v. Linde Air Prods. Co., 339 U.S. 605, 607 (1950).

70. Le Roy v. Tatham, 55 U.S. (14 How.) 156, 175 (1853). 
often do employ abstract ideas or scientific principles to a useful and practical end, and when they do they are entitled to a patent. The worry is not that an inventor controls the application of an abstract idea, but only that an inventor obtains rights over the idea itself. That is, the abstract ideas exception operates where a patent claim is "too broad" in the sense that it encroaches upon society's right to unfettered access to scientific truths, fundamental principles, and the like; these properly belong in the commons upon which future innovations can be built, "free to all men and reserved exclusively to none."71

This concern about overbreadth is not, we think, limited to the abstract ideas doctrine; it also animates the prohibition against patenting products of nature. Here, the law has repeatedly emphasized that the patent law is designed to protect applications of human ingenuity, not simply "nature's handiwork.",72 Thus, while a man-made organism is eligible for patentability, ${ }^{73}$ a natural bacterium is not. ${ }^{74}$ But natural products or phenomena can be patented when they are put to a specific new use. The boundary is neither the form of the invention nor its ability to "transform" nature; instead the analysis turns on whether the patent claims describe the application of human knowledge to a practical end, rather than merely identification of the existence of useful properties. In this way, a claim to an abstract idea is like a claim to a product of nature: not limited to real-world applications of human inventiveness, and thus ineligible for patenting.

Understood in this way, the abstract ideas doctrine is not about finding a conceptual category of inventions that is entitled to no protection at all, nor about determining the quality of the disclosure. Instead, it is about encouraging cumulative innovation and furthering societal norms regarding access to knowledge by preventing patentees from claiming broad ownership over fields of exploration rather than specific applications of those fields. Boiling these principles down to a practical test is a more difficult task. The abstract ideas exception should disallow those claims to ideas unmoored to real-world applications, taking into account the extent to which the claim forecloses after-arising embodiments of the idea, the nature and extent of the prior art, and the level of disclosure by the inventor.

\section{Distinguishing the Scope Limitations in $\S 101$ and $\S 112$}

Patent law has other doctrines that limit the scope of claims. Section 112 requires that a patentee claim no more than she has described in writing and

71. Funk Bros. Seed Co. v. Kalo Inoculant Co., 333 U.S. 127, 130 (1948).

72. Diamond v. Chakrabarty, 447 U.S. 303, 310 (1980); see also Funk Bros., 333 U.S. at 131 .

73. See Chakrabarty, 447 U.S. at 310.

74. See Funk Bros., 333 U.S. at 131. 
taught others how to make and use. ${ }^{75}$ But overbreadth as a limitation on a patentable subject matter differs in motivation and effect from scope limitations imposed under $\S 112$.

First, $\S 112$ merely examines whether the disclosure is sufficient to warrant the claims. ${ }^{76}$ While some claims may be too broad in light of the disclosure, they are not necessarily abstract ideas. ${ }^{77}$ Relatedly, enablement does not provide enough of a limitation on scope as the level of skill in the art goes up. ${ }^{78}$ Overclaiming under $\S 101$, on the other hand, is primarily concerned with removing obstructions to follow-on innovation. The question is not whether one could make the embodiments claimed, but rather whether the inventor has contributed enough to merit a claim so broad that others will be locked out. ${ }^{79}$

Removing certain inventions-particularly inventive principles-from patentability diminishes burdens to follow-on inventors who might make use of those principles in new embodiments or applications of the principle. If we allowed exclusionary rights over broad principles, later inventors wanting to employ those principles in new inventions would need to license rights to the original patent, thereby increasing the costs to follow-on invention. The precise level of "abstractness" of a given claim at which follow-on invention is overly burdened is somewhat arbitrary. ${ }^{80}$ Nonetheless, when a patent claim would foreclose all future embodiments or applications of the inventive principle claimed in a patent, courts have balked. That is true even if the patentee has enabled others to use all currently known embodiments, thus satisfying $\S 112$. In the words of the Supreme Court, such claims "wholly pre-empt” all present and future uses of the inventive principle. ${ }^{81}$

Second, the enablement and written description requirements of § 112 concern the adequacy of the inventor's disclosure at the time of filing. Scope concerns under $\S 101$, however, relate to the possibility of invention after filing. Indeed, under $\S 112$, as long as an inventor sufficiently discloses those embo-

75. See 35 U.S.C. § 112 (2006).

76. See The Incandescent Lamp Patent, 159 U.S. 465, 474 (1895) (holding that claim to light filaments made from any carbonized textile or vegetable fiber was too broad in light of disclosure that described only one type of fiber).

77. See, e.g., id. While the filament claims were broader than the disclosure allowed, they were not abstract.

78. See Dan L. Burk \& Mark A. Lemley, Is Patent Law Technology-Specific?, 17 BERKELEY TECH. L.J. 1155, 1164-65 (2002) (arguing that judicial attribution of high skill level to programmers has nullified enablement requirement for software patents); Michael Risch, A Brief Defense of the Written Description Requirement, 119 Yale L.J. ONLINE 127, 138-39 (2010) (arguing that description is critical because high skill means more claims with less disclosure of actual invention).

79. One of the authors has argued that we could accomplish the same end with a more capacious understanding of $\S 112$. Risch, supra note 61 , at 591 . But we currently do not have such an understanding.

80. See infra Part III.

81. Bilski v. Kappos, 130 S. Ct. 3218, 3230 (2010) (quoting Gottschalk v. Benson, 409 U.S. 63, 72 (1972)). 
diments of the invention that could have been built at the time of filing, the inventor will generally be afforded exclusionary rights over later inventions that use after-arising technology - technology that did not exist at the time of filing. Section 101, on the other hand, concerns itself precisely with the degree to which a patent claim will foreclose later-developed technology. Thus, even an inventor meeting the requirements of $\S 112$ may write a claim so broad as to violate $\S 101$. This distinction in timing is critical to understanding the differences in patent scope thresholds under the two sections.

By removing overly abstract inventions from patenting, we drive more competition in research and development races to complete practical, applied inventions. In other words, by moving patenting downstream, we both permit competition in research and development and encourage competition among the practical, applied inventions developed by that research. ${ }^{82}$ Thus, by limiting claims to practical applications, as opposed to broadly claimed abstract inventions, we help promote the goal of stimulating optimal invention. Section 112 may have the prevention of gun jumping as a subsidiary goal, but an overclaiming view of $\S 101$ puts the primary focus on whether the claims reflect an applied principle.

Finally, the enablement inquiry itself is extremely difficult and fraught with contradiction. ${ }^{83}$ Our focus under $\S 101$ on claim scope with an eye toward practical application provides for a different type of analysis. It may be that claims are not abstract but also not enabled (like Incandescent Lamp) or it may be that claims are abstract, but enabled (like Benson).

Similarly, definiteness concerns under $\S 112$, paragraph 2, inform but do not replace our standard. Definiteness asks whether a person having ordinary skill in the art (PHOSITA) could understand the claims, regardless of how abstract or applied they might be. Bilski’s claim to hedging was understandable, even if it was overbroad. Under $\S 101$, we are concerned about the uncertainty and vagueness of claims over abstract ideas or natural laws that could thwart optimal invention by closing off avenues not invented (or inventible) by the patentee. Claims that are indefinite under $\S 101$ may be clear in their language but

82. See Christopher A. Cotropia, The Folly of Early Filing in Patent Law, 61 HASTINGS L.J. 65, 127 (2009) (arguing that inventions should be reduced to practice to improve commercialization); see also Michael Risch, Reinventing Usefulness, 2010 BYU L. REV. 1195, 1224-34 (discussing practical utility as a commercialization lever); Ted Sichelman, Commercializing Patents, 62 STAN. L. REV. 341, 343 (2010) (discussing incentives provided by patent law to commercialize inventions).

83. See, e.g., T.J. Chiang, The Levels of Abstraction Problem in Patent Law, 106 Nw. U. L. REV. (forthcoming 2011) (manuscript at 6), available at http://papers.ssrn.com/sol3/ papers.cfm?abstract_id=1434465 (noting that determining whether a claim is enabled requires us to choose the level of abstraction at which we assess that claim); Timothy R. Holbrook, Patents, Presumptions, and Public Notice, 86 InD. L.J. (forthcoming 2011) (manuscript at 18-19), available at http://ssrn.com/abstract=1650819; Jeffrey A. Lefstin, The Formal Structure of Patent Law and the Limits of Enablement, 23 BERKELEY TECH. L.J. 1141, 1168 (2008). 
still lead to indeterminate results because they claim activities that are not under the control of the person practicing the method. ${ }^{84}$

\section{Scope Limitation in the Case Law}

In our view, the theory articulated here explains most of the major cases implementing the $\S 101$ abstract ideas exception.

\section{Historic cases}

Three historic cases illustrate how excluding abstract ideas limits claim scope. In O'Reilly v. Morse, the Supreme Court considered Samuel Morse's patent on the telegraph. ${ }^{85}$ It allowed what many would consider today to be a business method claim: "the system of signs, consisting of dots and spaces, ... . in combination with machinery for recording them, as signals for telegraphic purposes." ${ }^{\prime 86}$ It also allowed Morse’s claim to his particular telegraph. However, the Court denied Morse's claim to all transmission of printed information by an electromagnetic signal by any means. ${ }^{87}$ While the Court had no problem with patenting a particular form of such transmission - the telegraph—it invalidated the broader claim because Morse claimed all forms of printing at a distance without tying the claim to any process or machinery disclosed in the patent. $^{88}$

It is no surprise that many consider Morse to be an enablement case. ${ }^{89}$ But this explanation is incomplete, because the Court's ruling goes beyond ordinary application of enablement. The Court's concern is not just undue experimentation necessary to achieve the broad claim scope. ${ }^{90}$ Nor can the case solely be explained on the grounds of the written description doctrine. ${ }^{91}$ Although the Court stated that Morse "claims an exclusive right to use a manner and process

84. There may also be distributive concerns in $\S 101$ analysis: subject matter jurisprudence consistently recites that certain principles must be "free to all men." Funk Bros. Seed Co. v. Kalo Inoculant Co., 333 U.S. 127, 130 (1948). This language is not present in enablement and definiteness cases.

85. 56 U.S. (15 How.) 62 (1854).

86. Id. at 86.

87. See id. at 112-17.

88. See id. at 113; see also id. at 118-19 (describing the importance of description of the patented invention).

89. See, e.g., Craig Allen Nard, The Law of Patents 51 (2008) (presenting Morse at the beginning of a patent textbook section on enablement).

90. Cf. The Incandescent Lamp Patent, 159 U.S. 465 (1895) (holding that enablement is based on undue experimentation); In re Wands, 858 F.2d 731, 737 (Fed. Cir. 1988) (describing factors to consider for undue experimentation in enablement).

91. Cf. Ariad Pharm., Inc. v. Eli Lilly \& Co., 598 F.3d 1336, 1346 n.4 (Fed. Cir. 2010) ("Morse, decided under the 1836 Act, can also be interpreted as involving a separate written description inquiry.”). 
which he has not described," it goes further by stating Morse's claim would foreclose "future inventor[s]" who "may discover a mode of writing or printing at a distance by means of the electric or galvanic current," that is, after-arising technology. ${ }^{92}$

Written description-like enablement-is measured at the time of filing. Thus, even claims that meet the written description requirement will generally foreclose "future inventors" who find new "means" of implementing the claimed invention, particularly for complex inventions composed of many separate components, any one of which might be replaced by after-arising technology that still falls within the literal scope of the claim language. Thus, the concern about follow-on invention in Morse cannot merely be explained by standard disclosure doctrines. Morse had, after all, taught the only way known at the time to use magnetism to print characters at a difference, so arguably he had satisfied the enablement standard as we understand it today. Instead, the Court's concerns require a separate theory of scope, one premised on patent eligibility of overly abstract claims.

In contrast with Morse's claim is Bell's patent on the telephone, which was upheld in the Telephone Cases. ${ }^{93}$ Bell discovered that voice could be transmitted over a closed circuit by varying the amplitude of the electrical signal; this discovery solved a problem that inventors attempting to transmit voices by opening and closing circuits (like the telegraph) could not solve. Bell, however, was a prophetic inventor who did not complete a working embodiment before he applied for his patent. ${ }^{94}$ Indeed, he only described one embodiment of his broad claims. Further, though Bell claimed two ways to transmit speech-the vibration and the variable resistance method - the device he described would only use one of the two ways, the vibration method. ${ }^{95}$ And Bell did not describe how to make a device to practice the other way. ${ }^{96}$

Nonetheless, the Court allowed a claim to the broad process of sending voice using either the vibration or the variable resistance method. The Court focused not on Bell's failure, but on the practical use of his principle. ${ }^{97}$

The Telephone Cases also mix concerns of disclosure under the enablement doctrine with concerns about follow-on invention. Whether Bell provided sufficient disclosure to support his claim is a question of enablement-and, perhaps, in modern parlance, of written description. But whether the claim was sufficiently specific - here, claiming a "practicable way of putting [the principle] into operation"98_is a $\S 101$ overbreadth issue, because the specificity

92. Morse, 56 U.S. (15 How.) at 113.

93. 126 U.S. 1 (1888).

94. See id. at 535.

95. See id. at 538.

96. See id.

97. See id. at 536.

98. Id. 
of the claim affects the latitude with which follow-on invention may be undertaken.

In this latter respect, the Court made two important statements. First, the Court noted that Bell was not claiming more than a very specific application of the principle that he invented: "Both forms of apparatus operate on a closed circuit by gradual changes of intensity, and not by alternately making and breaking the circuit . . .."99 Second, the Court noted that the general principle of gradual electrical changes provided a specific, applied solution that was not available before. ${ }^{100}$

Bell was entitled to the general and broad method that he discovered because he was able to describe "the exact electrical condition that must be created to accomplish his purpose."101 The Court distinguished this from Morse's unapplied claim to all electromagnetic transmissions by any means:

It may be that electricity cannot be used at all for the transmission of speech except in the way Bell has discovered, and that therefore, practically, his patent gives him its exclusive use for that purpose, but that does not make his claim one for the use of electricity distinct from the particular process with which it is connected in his patent. ${ }^{102}$

Here, too, the question is whether Bell attempted to claim more than a new, specific, practical, and applied benefit. The Court said no-the specific solution to a specific problem might have broad application, but it was an application of the inventive principle. Other inventors remained free to investigate other ways of communicating voice over an electric wire because Bell did not claim all transmissions of voice by any means or machinery.

A third example is Mackay Radio, in which a well-known equation predicted the optimal wire lengths for receiving radio signals. ${ }^{103}$ The patentee (who did not discover the equation) claimed an antenna using these lengths. The Supreme Court held that the antenna was a patent-eligible application of the equation: "While a scientific truth, or the mathematical expression of it, is not patentable invention, a novel and useful structure created with the aid of knowledge of scientific truth may be."104 The Court made clear that claim scope was the key factor in determining whether the antenna was patentable, and that the application of a known principle would be narrowly construed. ${ }^{105}$

Mackay illustrates two fundamental points in our theory. First, practical applications of so-called "abstract ideas" are patentable. Second, consideration of a claim's contribution to applied uses is a matter of claim scope. Applying a

99. Id. at 538.

100. See id. at 544 .

101. Id. at 535.

102. Id.

103. Mackay Radio \& Tel. Co. v. Radio Corp. of Am., 306 U.S. 86, 93-94 (1939).

104. Id. at 94 .

105. See id. 
basic scientific principle to the construction of a useful object is patentable; claiming every use of that principle isn't.

\section{Modern Supreme Court cases}

Our scope theory is also largely consistent with the Court's more recent "abstract idea" decisions. In Gottschalk v. Benson, the Court invalidated a claim to a process for converting binary coded decimal numbers into pure binary format. ${ }^{106}$ The method was well-known, and could be done by pencil, but had not been implemented by computer. ${ }^{107}$ The process claim, the Court ruled, was simply too broad and untied to any application, especially in comparison to the contribution of the inventor: "Here the 'process' claim is so abstract and sweeping as to cover both known and unknown uses of the BCD to pure binary conversion. The end use may . . . be performed through any existing machinery or future-devised machinery or without any apparatus." ${ }^{108}$ In short, whatever was new about the invention was unmoored to any practical application, such that it was "so abstract and sweeping" as to unduly foreclose follow-on invention, particularly that using after-arising technologies. Given the Court's concern with "unknown uses" and "future-devised machinery," Benson cannot merely be explained by traditional scope and disclosure doctrines.

Nor are technology-driven explanations of Benson as rejecting all claims involving software or mathematical algorithms satisfying. For just nine years later in Diamond v. Diehr, without repudiating Benson, the Court upheld a process for curing rubber even though the process incorporated a well-known mathematical formula about how long to cure rubber. ${ }^{109}$ Diehr is a straightforward application of our theory-Diehr's process was tied to a specific practical application of the formula that did not unduly foreclose future innovation relying on the formula.

Even the outcome, though not the methodology, in the troublesome case of Parker v. Flook ${ }^{110}$ might be explained by our theory. In Flook, the Court ruled that a claimed method for updating an alarm limit in catalytic conversion using a specified algorithm was unpatentable under $\S 101 .^{111}$ The problematic aspect of the case is its apparent reliance on "point of novelty" analysis - treating the mathematical algorithms that were the novel feature of the invention as if they were already known. This approach is problematic in many respects, ${ }^{112}$ and for that reason it is tempting to dismiss the case as an outlier. Indeed, the Court's

106. 409 U.S. 63,65 (1972).

107. See id. at 67.

108. Id. at 68 .

109. 450 U.S. 175 , 187 (1981).

110. 437 U.S. 584 (1978).

111. Id. at 594 .

112. See, e.g., Mark A. Lemley, Point of Novelty, 106 Nw. U. L. REv. (forthcoming 2011), available at http://ssrn.com/abstract=1735045 (critiquing this aspect of Flook). 
holding on point of novelty was essentially overruled a few years later in Diehr. ${ }^{113}$

Despite its doctrinal problems, the outcome in Flook can be understood as consistent with our theory. The inventor claimed a general method of calculating "alarm limits" in a catalytic conversion process. ${ }^{114}$ The process, however, did not purport to measure temperature, pressure, volume, or any other specific aspect of the catalytic conversion process. Thus, the claim was not tied to any application whatsoever. Yet the patent applicant wanted to bar all uses of the formula in any later application of it. Read this way, the Flook Court merely found that the patent applicant was claiming too broadly. The Court's analysis revealed that Flook's claim far exceeded — and indeed Flook never demonstrated-any real-world practical application, wholly preempting all present and future uses of the alarm-limit algorithm not only in catalytic conversion, but potentially elsewhere. Such a broad claim is properly barred by the abstract ideas exception.

The Court's rejection of Bilski's claimed method of hedging is consistent with our theory. The patent application in Bilski described a very specific way to use historic weather data to determine optimal prices for hedging transactions in particular commodities. ${ }^{115}$ Yet the first claim sought to patent all such hedging transactions, at any price, for any commodity. ${ }^{116}$ Like the other patent applicants outlined here, Bilski claimed too broadly-effectively seeking to control the idea of hedging, unmoored to the practical applications the inventor actually disclosed.

We do think this analysis points to a failing in the Court's Bilski opinion: it is too quick to reject each of the other claims. While close analysis may reveal that each of Bilski's narrower claims was still too broad, the Court gave short shrift to such considerations. It is possible that Bilski narrowed the dependent claims sufficiently to cover only a specific, practical, even novel application.

Finally, our theory provides the only reasonable explanation of the Federal Circuit's decision in In re Abele, ${ }^{117}$ which otherwise seems an outlier. In Abele, the applicants invented an improvement in digital x-ray data processing that allowed for better imaging while exposing patients to less radiation. ${ }^{118}$ The invention involved narrowing an x-ray beam in order to reduce exposure, and a companion method of calculating the image data to correct for the deficiencies caused by a narrower beam. ${ }^{119}$

113. 450 U.S. at 187.

114. See In re Flook, 559 F.2d 21, 22 (C.C.P.A. 1977), rev'd sub nom. Parker v. Flook, 437 U.S. 584 (1978).

115. See Brief Amici Curiae of 20 Law and Business Professors in Support of Neither Party at 31-32, Bilski v. Kappos, 130 S. Ct. 3218 (2010) (No. 08-964).

116. See Bilski, 130 S. Ct. at 3223-24.

117. 684 F.2d 902 (C.C.P.A. 1982).

118. See id. at 903.

119. See id. at 904. 
The case involved two claims. Claim 5 covered a "method of displaying data" using certain calculations. Claim 6 was the same as claim 5, but limited to specific x-ray attenuation data. ${ }^{120}$ The court rejected the broad claim 5 , but upheld the narrower claim 6 . This result cannot be explained by saying that the broad claim did not transform anything, while the narrow claim did. Claim 5 encompasses-without question-a specific way to process and display an image. If, however, one were to focus on the intangibility of the result it produces-images on a computer screen - then the x-ray related claim must also be an abstract idea. Those images are merely a subset of the images claimed in the broader claim, and processing x-ray data is no less abstract than processing other data. Nor can this result be justified by arguing-as the Federal Circuit does in formulating the machine-or-transformation test-that the data in claim 6 represents "physical" phenomena while the data in claim 5 does not. ${ }^{121}$ Claim 5 describes the display of a picture to which the data is related. A picture must necessarily be of something physical, so that the data must necessarily be related to something physical.

The best, and perhaps only, explanation for this result is that claim 5 was simply too broad. While claim 6 is grounded in a particular application with practical results relating to $\mathrm{x}$-ray technology, claim 5 is untethered to any specific application or technology. While the picture of claim 5 was physical in some sense, there is no limitation whatsoever on what the picture might be of. Thus, the claim effectively covers all uses of the algorithm to improve the image quality of the picture under consideration, foreclosing all present and future uses of the algorithm. Like the invalid claims in Morse, Benson, Flook, and Diehr, such broad claims are too abstract.

In short, we think the overclaiming approach is amply supported in the case law. The problem is that courts have not uniformly followed Diehr, nor have they explained the abstract ideas doctrine in a consistent and coherent way. The result has been that courts fall back on "clues" like the machine-ortransformation test that, even if based in a theory of overclaiming, disserve that goal in practice.

\section{A PROPER APPROACH TO IDENTIFYING CLAIMS THAT IMPERMISSIBLY COVER ABSTRACT IDEAS}

Focusing on claim scope provides a principled way to determine whether a particular claim, rather than a particular subject matter, is unpatentable. Specifically, our approach focuses on the application of the idea to determine the proper level of abstraction that merits protection. As claims become broaderand necessarily more general and abstract - they become more indefinite and difficult to understand, and more likely to ensnare future inventions embodying

120. See id. at 908 .

121. See In re Bilski, 545 F.3d 943, 962-63 (Fed. Cir. 2008) (en banc). 
the inventive principle. At their limit, they claim everything and contribute nothing. The practical effect of allowing such breadth is to make later improvements more costly or even impossible.

To be sure, identifying overclaiming is not straightforward, and no test will yield conclusive answers. Yet we believe some tests are clearly more workable - and better further the policy-based goals of § 101—than others. This Part discusses why the machine-or-transformation test is unsuitable, and then provides a better way to identify improper claims.

\section{A. The Failure of the Machine-or-Transformation Test}

As discussed in Part I, continued reliance on the machine-or-transformation test is problematic because that test has little to do with claim scope. For example, it fails to identify why the claims in Benson and Flook should be unpatentable when both are unambiguously performed by a machine. To be sure, the insignificant postsolution activity test provides an exception to the rule, but every software patent will be executed on a machine. If every such claim is reviewed for "insignificant" activity, the exception becomes the rule without any definition of what "insignificance" is.

A focus on physicality fares no better. For instance, the Federal Circuit held in Prometheus that the claimed medical diagnostic test sufficiently transformed matter, because "[t]he transformation is of the human body following administration of a drug."122 Chemical transformations that occur within the body, however, could just as plausibly be characterized as "insignificant extrasolution activity," because they simply relate to a mere "data-gathering step”123 that is tangential to the process performed directly by the diagnostic test. The court's conclusory reasoning about transformation does not answer the question; as Abele shows, a method may transform data about physical subject matter but still be too broad.

The problem is that the machine-or-transformation test simply asks the wrong question. For example, in Comiskey, the arbitration process was unpatentable not because it lacked a computer, but because the claim embraced countless arbitration arrangements untied to any practical application of their idea. The application claimed too much.

This is likely to be a recurring problem in software cases in particular. The genius of computer technology is that it is a platform that allows creation to occur on it. A computer program can be claimed in terms specific or general, but today (except by happenstance) it would rarely be logically limited to running on a particular type of hardware. Requiring that software claims be tied to particular machines would indeed impose a limitation on their scope, but the limi-

122. Prometheus Labs., Inc. v. Mayo Collaborative Servs., 581 F.3d 1336, 1346 (Fed. Cir. 2009), vacated and remanded, 130 S. Ct. 3543 (2010).

123. In re Bilski, 545 F.3d at 963. 
tation would bear no relationship to what the patentee actually invented. The first programmer to build a dynamic linked list shouldn't own the concept, and it doesn't help to say that he owns the concept when implemented on a Dell computer but not a Mac. Limiting the scope of a patent claim makes sense only if the limitation bears some relationship to the inventive aspect of the claimed invention. In software patents, hardware is almost never the inventive aspect.

Machines and transformations may be relevant to this inquiry, but only as a way to conceptualize whether a claim is overbroad. Treating machine-ortransformation as a proxy or other subpart of a gatekeeping test is ill-advised.

\section{B. Identifying Abstract Ideas}

Claims are proper when the scope of the patentee's claims is commensurate with a practical, real world contribution the patentee has made. They are too broad when they assert coverage over general ideas unmoored to any specific use, and therefore deprive subsequent researchers of access to those ideas. Make no mistake-determining whether claims are abstract must be performed case by case. Even so, courts and litigants need not be entirely at sea. We have rules (and standards) that guide us in determining whether a claim is enabled, novel, and so forth. Here, too, we have a baseline requirement: that the claim be tied to a practical, applied contribution of the inventor. The factors that follow are tools to answer this question, but the question itself is one that can have a principled answer.

One factor that courts should consider is the generative nature of the new technology. Is the claimed invention one with a very limited set of possible applications? If so, we might not worry about locking up future avenues of research. Patent claims to inventions that are ends in themselves, rather than means to new ends, are less likely to create $\S 101$ overbreadth problems. The Benson Court worried that the patentee would lock up the principle of binarycoded-decimal conversion. But the more specific a mathematical algorithm gets, the less likely it is to be useful outside the context of the patented invention. If Windows 7 is a mathematical algorithm (and in one sense, it is), it is not one we need worry much about preventing others from using for different ends. By contrast, the newer a field, and the more likely it is to have a variety of applications, the more reluctant we should be to award ownership of generative building blocks to people who have not yet explored how they may be applied.

Second, the nature of the industry in which the invention occurs may be relevant. While all inventors depend to some extent on the work of others, some industries are more likely to rely on cumulative innovation than others, and the danger of allowing patents on abstract claims is correspondingly greater in those industries. We think that explains why we have seen abstract idea cases almost exclusively in the electronic and computer arts, rather than in, say, the 
pharmaceutical industry. ${ }^{124}$ That is not to say a patentee could never overclaim in a mechanical art. Imagine, for instance, the inventor of the first catheter claiming "any means, however developed, for noninvasive surgical intervention in the human body." But the damage that such broad claims can do will be greater in industries that rely more heavily on cumulative innovation. ${ }^{125}$

Third, on a related note, industries differ in the speed with which advances are made. Because patents expire after twenty years, the cost of an overbroad patent claim may be less in a slow-moving field than in one that changes quickly. The Morse Court was prescient to suggest that eventually someone might happen upon other means than the telegraph of using electromagnetism to communicate at a distance, but as it happened, Morse's patent claims would have expired by the time the first of those new technologies was developed. But that will not always be the case, and in newer and faster-changing industries the risk of stifling after-arising technology is greater.

Fourth, courts should be particularly wary of general claims to a principle based on one or very few specific applications. When a patentee identifies only one specific application, but claims a very broad principle, it is more likely that the broader claim will encompass unanticipated applications. This situation increases the likelihood that others will need access to the claimed principle, access that might be denied or limited to the public's detriment. To be sure, written description and enablement analysis under $\S 112$ also examines such concerns; claims that are not described and enabled are also more likely to be abstract. When applied to abstract ideas, however, this factor can extend beyond $\S 112$. Because $\S 101$ is not tied to the filing date of the application, courts can consider potential (even hypothetical) technologies that might technically be enabled, but that are not supported by the application presented by the inventor. Further, § 112 sometimes permits patentees to claim a genus by relying on only a single example. While one example may enable one of skill in the art to practice a range of alternatives, $§ 101$ might still impose limits on the resulting claim.

Fifth, courts should consider the importance of the patentee's contribution. Strictly speaking, importance has no bearing on how abstract the patentee's claims are, but as we indicated earlier, overclaiming is about balancing the incentives needed for the patentee against the risk of stifling future innovation. Truly groundbreaking patents may require broader protection for the simple reason that an inventor who opens up a new field may have less idea how her invention will be used by others. We can't effectively assess that balance unless we have some sense of how important the patentee's invention is, as well as

124. See, e.g., Dan L. Burk \& Mark A. Lemley, The Patent Crisis and How the COURTS CAN SOLVE IT 142-66 (2009) (identifying abstract ideas doctrine as a policy lever that is likely to be more important in some industries than others).

125. The authors are not of one mind as to whether (and how much) courts should expressly consider the industry in deciding abstractness, but there is little question that abstract ideas claims will be more common in certain industries. 
how important the future innovation might be. An old doctrine once held that "pioneering" patents were to be given broad scope. ${ }^{126}$ That doctrine is now moribund, brought down by the singular focus on patent claim language to define an invention's scope. Yet the idea of pioneering patents might usefully be applied in this different context to give greater leeway to those who arguably teach more. The more important the patentee's contribution, the more we should err on the side of allowing broad claims at the margins. ${ }^{127}$

In sum, we believe at least five factors are critical to a proper scope-based determination for patentable subject matter eligibility under $\S 101$ :

- Is the claimed invention potentially generative of many kinds of new inventions?

- Does the industry rely heavily on cumulative invention?

- Is the technological field fast-moving?

- Has the patentee disclosed a small number of embodiments but claimed a broad inventive principle?

- Has the patentee made an important contribution relative to the prior art?

No one factor should dominate; we advocate a contextual, common-law approach. Courts and scholars are likely to develop other factors as our approach is applied over time.

\section{Overclaiming and the Decision Process}

Finally, thinking about $\S 101$ and the abstract ideas doctrine as scope limitations may help change the way we approach subject matter procedurally. The "gatekeeper" theory carries with it the logical consequence that $\S 101$ eligibility should be decided first. After all, if your invention isn’t eligible for patenting at all, we don't need to figure out whether it's new and nonobvious and whether you have taught people how to make and use it. And so the Federal Circuit in

126. See, e.g., Miller v. Eagle Mfg. Co., 151 U.S. 186, 207 (1894) ("If the invention is broad or primary in its character, the range of equivalents will be correspondingly broad, under the liberal construction which the courts give to such inventions.”); Perkin-Elmer Corp. v. Westinghouse Elec. Corp., 822 F.2d 1528, 1532 (Fed. Cir. 1987) (“A pioneer invention is entitled to a broad range of equivalents.”); John R. Thomas, The Question Concerning Patent Law and Pioneer Inventions, 10 HigH TECH. L.J. 35, 37 (1995) ("Courts construe pioneer patent claims ... to encompass a broader range of so-called 'equivalents' during an infringement determination.”).

127. See Kokomo Fence Mach. Co. v. Kitselman, 189 U.S. 8, 18-19 (1903) (“In view of what passed in the Patent Office, and the state of the art, we cannot regard the Kitselman patent as a pioneer patent, but think its claims must be limited in their scope to the actual combination of essential parts as shown ....”). 
Comiskey strongly suggested, if not required, that $\S 101$ be decided before everything else. ${ }^{128}$

That is a mistake. There were many, many ways to reject Bilski's claim 1. As a result, both the Federal Circuit and the Supreme Court approached the case with the preconception that Bilski should lose, and looked to the only available doctrine allowed by the procedural posture- $\S 101$ - to make sure that he did. ${ }^{129}$ And so neither court was too careful about the doctrine it created or how it applied that doctrine, because the result in that case was foreordained.

We think a subject-matter-first approach is backwards. Our claimoverbreadth approach requires careful attention to what the patentee invented, what came before, and what might come after. It can't logically be applied in advance of thinking about the other issues in a patent case. Indeed, we agree with a number of commentators that the right time to apply $\S 101$ is as a backstop after all other validity doctrines have been exhausted. ${ }^{130}$ We don't need the abstract ideas doctrine to weed out claims like Bilski's claim 1. Only once an invention is deemed new, nonobvious, described, and enabled should we ask whether there is nonetheless some reason to limit a claim. Asking the question later is likely both to produce a clearer answer - courts will have to think carefully about why they are rejecting such a claim—and to reduce the risk that we inappropriately carve entire areas of invention out of the patent system.

\section{Applying the Scope-Based Patentable Subject Matter Analysis}

We now apply our theory and factors to a variety of controversial claims. Of course, the evidence relating to these claims may differ from what we see in reported opinions; as such, reasonable minds can differ based on varying understandings of the factors involved.

We first address the PTO's request for examples of what might or might not constitute abstract ideas. While we believe that this Article might offer the PTO guidance, provision of specific examples would be fruitless. Indeed, that is the point of an overclaiming approach rather than a gatekeeper approach. We cannot know whether a particular claim is too abstract until we understand the inventive principles, prior art, industries, and potential downstream inventions. Of course, we can hypothesize, as we did with our example of the catheter inventor claiming "all noninvasive surgery," but such absurd claims are rare,

128. See In re Comiskey, 499 F.3d 1365, 1371 (Fed. Cir. 2007). But see In re Bilski, 545 F.3d at 950-51 n.1 (stating that Comiskey did not require patentable subject matter to be examined first).

129. Cf. Michael Risch, The Idea's the Thing, Legal Times, May 12, 2008, available at http://law.wvu.edu/r/download/9874 (expressing concern that the weakness of Bilski's application would cause courts to create over-restrictive subject matter rules).

130. See, e.g., Christopher T. Abernethy, Cruel Hand of Bilski: Culminating the Shortsighted Crusade for Marginalization of the 'Process' Patent 27-37 (May 2009) (unpublished comment), available at http://papers.ssrn.com/sol3/papers.cfm?abstract_id=1420205. 
and-like Bilski's-are almost always invalid for many reasons unrelated to their abstractness. We thus focus on some closer cases.

One such case is Metabolite, ${ }^{131}$ in which the patentee claimed a method for diagnosing a vitamin deficiency by measuring total homocysteine in the blood and correlating elevated levels with a deficiency. ${ }^{132}$ Three Justices argued that this claim was an unpatentable natural phenomenon. ${ }^{133}$ While some agree, others criticize this view because every medical diagnostic method (and most every treatment method) boils down to a natural phenomenon. ${ }^{134}$

Our analysis would instead focus on whether the claim is an application of the natural phenomena or whether it is so broad as to be unmoored from any specific application. It is difficult to dispute that the use of the relationship between total homocysteine and vitamin levels to diagnose a deficiency is applied in some sense, because it is implemented in a specific test that compares the relationship between two substances in the body. At the same time, the claim is broad, because any homocysteine test-including tests not yet invented-will infringe if it is used to diagnose the deficiency.

The question becomes whether the claim is overbroad in the $\S 101$ sense. Importantly, the claim does not preclude follow-on invention of new kinds of general diagnostic tests that measure the relationship between any and all substances in the body. Rather, the Metabolite test diagnoses a particular vitamin deficiency. Further, it uses one particular blood test-total homocysteines-not every blood test. Others are free to develop new blood measurements and new ways to test for this particular deficiency, even if they cannot use the particular method disclosed in the patent. And the claim does not cover other possible uses of the relationship, such as medical interventions that aim at reducing total homocysteine. Applying some of our factors, the technology was not generative and the industry is not particularly speedy, so the risk of locking up further improvements to this specific test seems low. Further, the claim appears to be tied to the disclosed embodiment because the inventors described the principles at work and the failures of other tests. In short, we find it unlikely that future inventors were blocked from creating new diagnostic tests in general, or even new ways to diagnose this particular deficiency. The primary concern, instead, was that downstream users would have to pay to exploit the discovery of the inventors, but that potential comes with every patent; there is no guarantee any downstream user will be able to invent around any particular patent claim.

131. Lab. Corp. of Am. Holdings v. Metabolite Labs., Inc., 126 S. Ct. 2921 (2006). Disclosure: Author Mark A. Lemley represented the patentee in this case.

132. See Metabolite Labs., Inc. v. Lab. Corp. of Am. Holdings, 370 F.3d 1354, 1358-59 (Fed. Cir. 2004), cert. dismissed, 126 S. Ct. 2921 (2006).

133. See Metabolite Labs., 126 S. Ct. at 2922, 2927 (Breyer, J., dissenting).

134. See Risch, supra note 61, at 600 ("Everything that happens may be deemed the work of nature .... .” (quoting Funk Bros. Seed Co. v. Kalo Inoculant Co., 333 U.S. 127, 134-35 (1948) (Frankfurter, J., concurring)) (internal quotation marks omitted)). 
Another medical diagnostic test example is Prometheus, ${ }^{135}$ in which the patentee claimed a method for adjusting medication for any given patient by measuring how much of the medicine's metabolites appear in that patient's body. ${ }^{136}$ The district court invalidated the patent because the amount of metabolization by any given patient was a natural phenomenon. ${ }^{137}$ The Federal Circuit reversed, holding (both before and again after Bilski) that because the drug was transformed in the human body — and indeed transformed the body itselfthe patent satisfied the machine-or-transformation test. ${ }^{138}$ Neither of these rulings is particularly helpful from an abstract ideas standpoint. The district court's focus was misplaced because there was nothing natural about the drug's effect on the body - it was an artificial drug and no human would ever react to it in nature. ${ }^{139}$

The Federal Circuit's analysis, by contrast, would allow too much. A patent claim can transform something and still be overbroad. If, for example, the patentee claimed all correlations of every drug in the body, the claim would certainly be abstract but would still pass the Federal Circuit's test. Our approach provides a way out of the thicket. Here, the claim was to very specific measurements of a particular drug. Like Metabolite, Prometheus involves an application of the natural principles discovered by the patentee. It is not generative, nor will it unduly bar future inventors. If, however, this claim were expanded to cover all drugs without any specific measurements, then it would be an abstract idea.

Metabolite and Prometheus concern inventions in the biotech and medical fields. Another field worthy of discussion is computer software. As we mentioned earlier, in Benson, the Supreme Court found a claimed algorithm used to convert data on a computer from one format to another was too broad, because it was not moored to any specific practical application. As such, it unduly prevented follow-on invention because it wholly preempted all use of the algorithm in any application whatsoever.

As we also noted, however, the Board of Patent Appeals \& Interferences has out-of-hand rejected software claims under the machine-or-transformation test that require a more rigorous analysis under our proposed test. For instance, in Ex parte Heuer, the Board rejected a claim to a method for decoding a binary

135. Mayo Collaborative Servs. v. Prometheus Labs., 130 S. Ct. 3543 (2010) (granting certiorari, vacating underlying judgment, and remanding for reconsideration in light of Bilski).

136. Prometheus Labs., Inc. v. Mayo Collaborative Servs., 581 F.3d 1336, 1340 (Fed. Cir. 2009), vacated and remanded, 130 S. Ct. 3543.

137. See Prometheus Labs. v. Mayo Collaborative Servs., No. 04cv1200, 2008 U.S. Dist. LEXIS 25062 (S.D. Cal. Mar. 28, 2008), rev'd, 581 F.3d 1336, vacated and remanded, 130 S. Ct. 3543.

138. See Prometheus, 581 F.3d at 1345-46; see also Prometheus Labs., Inc. v. Mayo Collaborative Servs., 628 F.3d 1347, 1349 (Fed. Cir. 2010) (on remand).

139. See Brief of Amici Curiae Interested Patent Law Professors in Support of Neither Party at 1, Prometheus, 581 F.3d 1336 (No. 2008-1403). 
representation of a document, finding that nothing in the specification required any "hardware" and therefore no machine was claimed under the machine-ortransformation test. ${ }^{140}$ Under an appropriate $\S 101$ scope analysis, the relevant concern is not whether there is a physical machine per se in the specification or claim language. Rather, the question should be whether the claim is so abstract and sweeping as to preclude all uses of the inventive idea, or whether it is sufficiently applied.

The proposed claim in Heuer is similar to that of Benson in that it concerns a method for converting a set of data from one format to another. Unlike the algorithm in Benson, however, the claim in Heuer does not cover a general algorithm, but instead a method of converting an XML-document that comprises particular steps. This factor weighs heavily in favor of patentability. On the other hand, those steps are relatively broad and cover implementations on any type of machine using any kind of XML data, including those not yet invented-indeed, the claim is not even limited to a general-purpose computer. Because the software industry is rapidly changing, under our proposed test one might argue that the claim should be moored to a specific type of computer or data structure to pass muster. Yet such an insistence would in essence require all software claims to be limited to those types of computers in use today. This kind of approach would unquestionably limit the value of software patents, and in a way that is unnecessary to adequately protect follow-on invention. Instead, a better way to cabin the broad scope of software patents is, in addition to determining whether the claim itself essentially covers merely the abstract idea at issue, to examine the contribution of the inventor relative to the prior art.

As we noted earlier, this examination is distinct from a $\S 112$ analysis. Although an inventor will often meet the written description and enablement standards by merely disclosing a few examples, for claims that could significantly impede follow-on invention (such as Heuer's) a more searching review may be advisable. Here, the question becomes whether Heuer disclosed sufficient embodiments to justify the relatively broad language in his proposed claim. In other words, does the disclosure justify the scope of preclusion of potential follow-on inventions embodying the general method claimed? This analysis will turn on the views of experts and others skilled in the relevant art, and thus, we cannot answer the $\S 101$ scope question at issue in Heuer here. Indeed, because this sort of analysis will not always be straightforward, we suggest that it be done last in any given case, after a review for novelty, nonobviousness, utility, and § 112 disclosure requirements.

Another difficult case under our test arises in the context of sports movessuch as patenting a new type of curveball. In some sense, a pitcher throwing a curveball might be argued to pass the machine-or-transformation test in the sense that the pitcher's body and the ball's location, velocity, and spin are

140. See Ex parte Heuer, No. 2009-004590, 2010 WL 3072973, at *8 (B.P.A.I. Aug. 4, 2010). 
transformed. ${ }^{141}$ The common intuition, however, is that this sort of claim should not be patentable subject matter, either because it does not concern technology or is too far afield from what is typically patentable. Apparently for this reason, the proposed PTO guidelines categorically classify "human behavior," particularly "exercising," as an example of a "general concept" that weighs against patent eligibility. Yet some human behavior-indeed, even some forms of exercise - should be eligible subject matter. Consider, for example, a novel method of exercising that helps relieve knee pain. Under the machine-or-transformation test, it is difficult to distinguish new exercise that is designed to cure a malady from one that merely increases the number of stristrikeouts.

However, under our proposed test-whether the claim is moored to specific, practical application - these distinctions are not as arbitrary. In particular, a novel exercise that helps cure knee pain would be a specific, practical application of the inventive ideas underlying the exercise. And this application would generally not foreclose other inventors from devising some new exercise to cure knee pain.

So too with a novel method of throwing a particular kind of curveball. A new motion that leads to a particular practical result with a baseball should probably be patentable. Arguably, patenting would not prevent follow-on invention if the claims were narrow. If, however, the claim were to every method of controlling ball motion using spin, then the claim would be more generative and likely too abstract. Pitching doesn't change rapidly. Nor is the claim not applied-this seems a very specific application of the general inventive principle. This is not to say that a new curveball is otherwise patentable-it may be obvious, it may not have operable utility, or it may not be definite. It is, however, allowable subject matter. ${ }^{142}$

\section{CONCLUSION}

The abstract ideas limitation on patentable subject matter has long been a puzzle, one Bilski did little to resolve. We think the dominant conception of $\S 101$ as a gatekeeper, excluding certain inventions from the patent system altogether, is wrong. We don't exclude inventions from patentability because the invention is too abstract. We refuse to patent certain claims when those claims reach too broadly and thereby threaten downstream innovation. Reconceiving abstract ideas as a scope limitation not only helps to explain the case law, but it

141. See Magliocca, supra note 52, at 876 n.7.

142. There may, of course, be "fairness" concerns in the game that counsel in favor of allowing pitchers to freely throw a new type of curveball, but such issues are best handled by league rules and not by courts determining what should be patentable. See Risch, supra note 61, at 645 . 
June 2011]

LIFE AFTER BILSKI

1347

avoids the disastrous consequences associated with the machine-ortransformation test. 
